\title{
A terrestrial Devonian-Carboniferous boundary section in East Greenland
}

\author{
John E. A. Marshall ${ }^{1}$ (iD \\ Received: 20 March 2020 / Revised: 15 July 2020 / Accepted: 22 July 2020 / Published online: 2 October 2020 \\ (C) The Author(s) 2020
}

\begin{abstract}
Terrestrial Devonian-Carboniferous boundary sections are present in the East Greenland Devonian Basin. The boundary section on Stensiö Bjerg developed in deep, distal lake sediments with a pair of lakes representing the boundary. A diverse spore assemblage developed as the lake flooded the basin. Previously abundant spores, notably Retispora lepidophyta, Diducites spp., Rugospora radiata and all forms with bifurcate tips (Ancyrospora and Hystricosporites), then became extinct through just over a metre of section. The spore assemblage is then lost into AOM rich very high TOC\% lake sediments. There is a negative $\delta^{13} \mathrm{C}_{\mathrm{TOC}}$ excursion in the Stensiö Bjerg section interpreted to represent the upper part of the positive excursion known from marine sections. The upper lake contains the simple VI spore assemblage of the earliest Carboniferous age. The correlative section on Rebild Bakker was developed in shallow proximal facies without AOM and shows that a Devonian-Carboniferous $\mathrm{LN}^{*}$ to VI spore zone boundary can be picked in the lower lake based on the last occurrence of Retispora lepidophyta in an assemblage otherwise dominated by simple spores and Grandispora cornuta. Spores in this VI spore assemblage, particularly Grandispora cornuta, show sculpture malformation that is entirely characteristic of UV-B radiation damage to their DNA prior to deposition of its protective wall layer. This palynological record showing the rapid extinction of major elements within the Late Devonian microflora can be reconciled with accounts claiming there was no mass extinction of plants and spores across the boundary. The palaeobiology of the major spore groups that became extinct is reviewed.
\end{abstract}

Keywords Devonian-Carboniferous boundary $\cdot$ Palynology $\cdot$ Spores $\cdot$ East Greenland $\cdot$ Extinction $\cdot$ UV-B

\section{Introduction}

There are a series of Devonian-Carboniferous boundary sections in the East Greenland Devonian Basin (Astin et al. 2010; Marshall et al. 1999). The East Greenland Devonian Basin was located (Torsvik and Cocks 2017) within the centre of the Old Red Sandstone (ORS) Continent that was the terrestrial land mass of Euramerica and characterised by red clastic sediments. The Greenland sections were at an estimated $1000 \mathrm{~km}$ from the sea (Marshall et al. 2007). This remoteness means the sedimentary system within the basin was immune

This article is a contribution to the special issue "Global review of the Devonian-Carboniferous Boundary"

John E. A. Marshall

jeam@soton.ac.uk

1 School of Ocean \& Earth Science, University of Southampton, National Oceanography Centre, European Way, Southampton SO14 3ZH, UK to events at the margins of the ORS Continent unless they were of sufficient magnitude to cause significant perturbations to the Earth System. These sections are probably the only known truly terrestrial sections with a recognised DevonianCarboniferous (D-C) boundary. Many other ORS sections were at the margins of the continent, and contain omission surfaces, unconformities and a marine transgression. The sedimentation rate within the actively extending basin in East Greenland was high with some $7 \mathrm{~km}$ of fluvial and aeolian sediments deposited from dryland river systems within the Givetian to Tournaisian interval that had a duration of 40 myr. These high sedimentation rates were present in the latest Famennian with the range of Retispora lepidophyta occupying some $230 \mathrm{~m}$ of section in Greenland, whereas in southern Belgium (e.g. Streel 1966), the same interval is $50 \mathrm{~m}$. The Greenland boundary sections are distributed across a 70-km transect (Fig. 1) within a lake system (Obrutschew Bjerg Formation) that replaced the normal dryland fluvial sedimentary system for the duration of the boundary perturbation. All of these sections are located at altitude (Stensiö Bjerg 


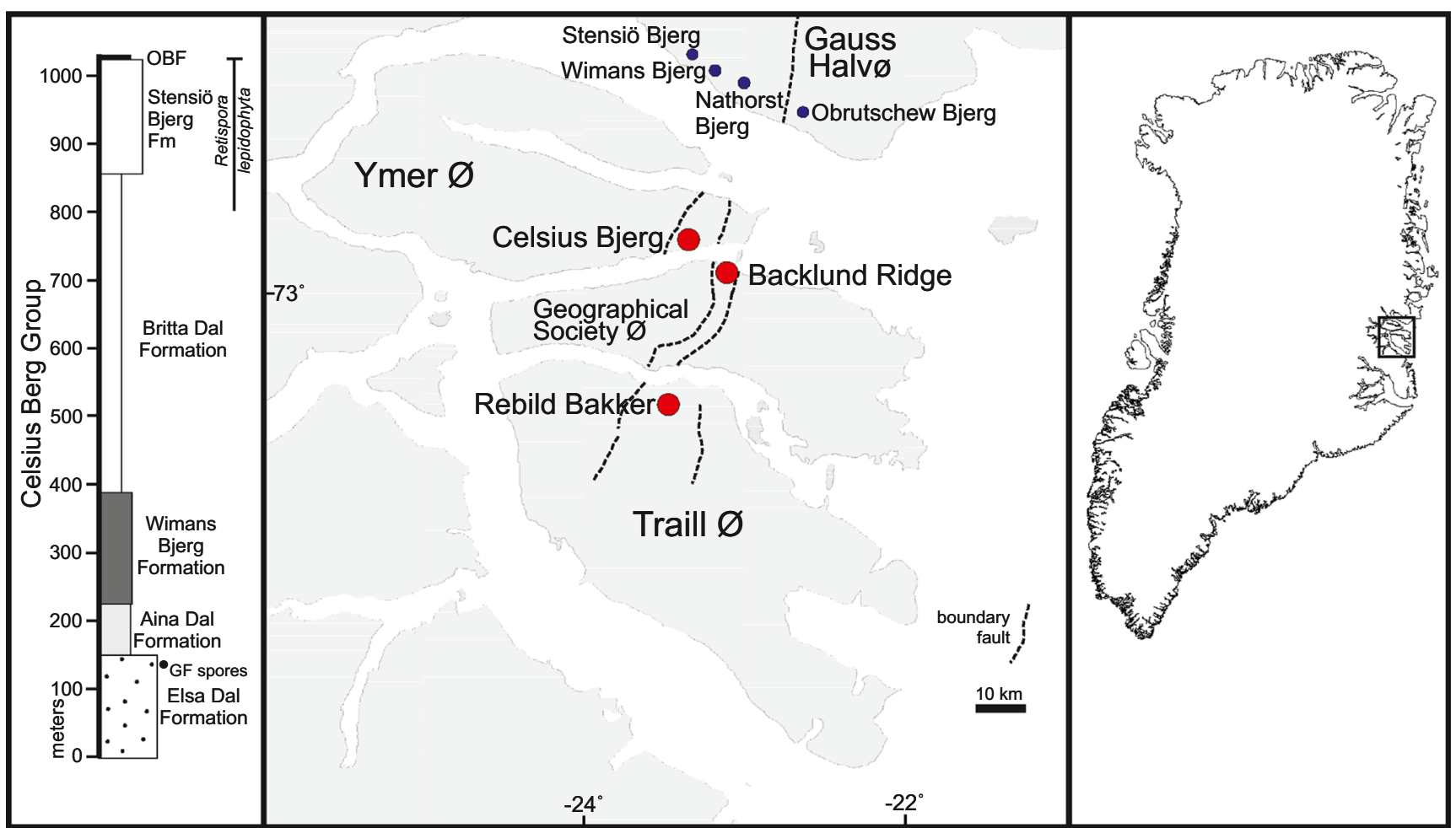

Fig. 1 Location of D-C boundary sections in East Greenland. Localities in blue are immediately beneath the base of the ?Permian unconformity. At Nathorst Bjerg, erosion has completely removed the Obrutschew
Formation. The localities in red have a preserved thick post-Devonian section above the Obrutschew Formation. Ø is island

On Gauss Halvø, the Obrutschew Bjerg Formation occurs (Fig. 1, OBF) on the mountains of Stensiö Bjerg, Wimans Bjerg and Obrutschew Bjerg where they are preserved immediately beneath the unconformity surface of an overlying "Rotliegend" equivalent (Marshall et al. 2019a) of probable Permian age. There is no unequivocal D-C boundary section on Nathorst Bjerg and the type section on Obrutschew Bjerg has been partially truncated by the "sub-Permian" erosional unconformity (Olsen and Larsen 1993). This makes Stensiö Bjerg the most complete section. It represents a pair of lake cycles that at their maximum development represented the deep and distal lake environment. In addition, it has earlier palynological preservation than other sections in the basin.

There are other relatively more proximal and shallower water lake sections that occur on a transect from Stensiö Bjerg to Celsius Bjerg (Ymer $\varnothing$ where $\varnothing$ is island) to Backlund Ridge (northern Geographical Society Ø) and then to the most marginally preserved lake facies at Rebild Bakker (Traill Ø). The section at Backlund Ridge is offset from the section line in the hanging wall of the Main Boundary Fault and preserves a locally more distal section. Unfortunately, the Backlund Ridge section has only intermittent exposure immediately above the D-C boundary.

These localities cover an area of $>10,000 \mathrm{~km}^{2}$ but apart from the Traill Ø locality, these other sites were not at the lake margin during the deepest parts of the lake cycles. This 
indicates that the lake occupied a much greater area, possibly encompassing the entirety of the East Greenland Devonian Basin. Comparing lacustrine facies and TOC\% content with other Devonian lakes from East Greenland (Marshall and Stephenson 1997; Marshall and Hemsley 2003; Marshall and Astin 1996) and elsewhere on the Old Red Sandstone Continent (Rogers and Astin 1991; Marshall and Fletcher 2002; Marshall et al. 2007) emphasises the size and depth of the Obrutschew Bjerg Formation lake. As such it represents a considerable body of "fresh" water that was present within what was previously an arid system at $15^{\circ} \mathrm{S}$ i.e. within the southern palaeoclimate zone. Under such a climate regime, a constant inflow of fresh water was required during the main mudstone deposition interval to maintain freshness of water as the system neither dried out nor turned to carbonate precipitation. As a contrast, the thin buff-coloured limestone (Fig. 2) between the lower and upper lake on Stensiö Bjerg represented such an interval when it reverted to a closed system. It is this requirement to balance the lake chemistry (cf. Marshall et al. 2007 for an example from the Orcadian Basin, Scotland) that indicates a significant discharge both into and out of the lake system and, by implication, a connection to the sea. It would be via this connection that the rather different fish fauna (palaeoniscid and a shark) gained access to the Obrutschew Bjerg Formation lake.

\section{Material and methods}

Sections were logged from Stensiö Bjerg, Nathorst Bjerg, Celsius Bjerg, Backlund Ridge and Rebild Bakker. The D-C boundary section at each locality was measured in detail where exposed and sampled at $10 \mathrm{~cm}$ resolution or better. From these sections, Stensiö Bjerg and Rebild Bakker have

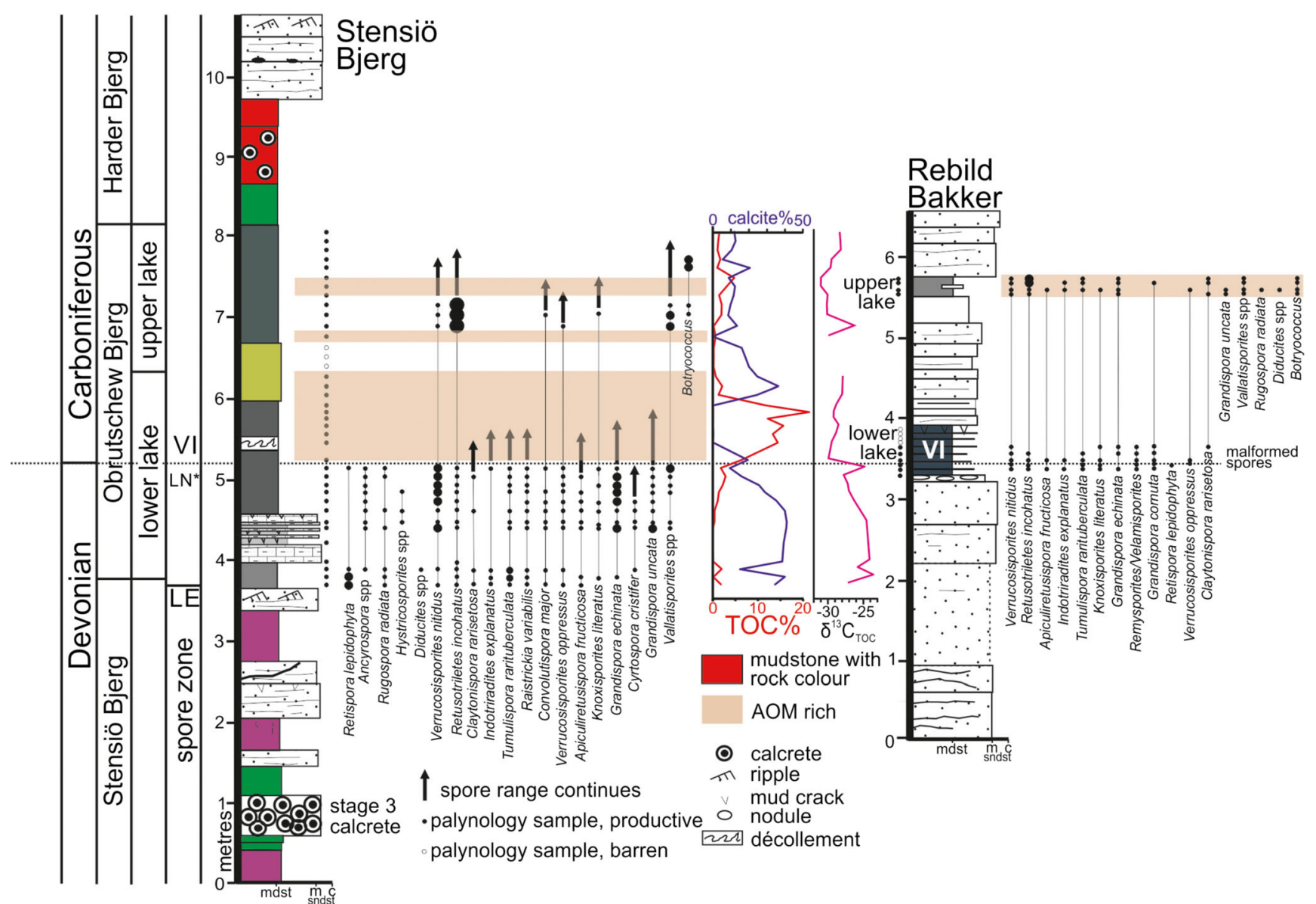

Fig. 2 Logs across the D-C boundary sections at Stensiö Bjerg and Rebild Bakker. At Stensiö Bjerg, a highly diverse spore assemblage rapidly declines with the extinction of a number of major clades through just over a metre of section before the record is lost in AOM-rich facies as also shown by the TOC\% profile. The next palynological assemblages are very different and from the VI spore zone of the Carboniferous age. The $\delta^{13} \mathrm{C}_{\mathrm{TOC}}$ record reveals a negative excursion interpreted as the upper part of the D-C positive excursion. The Rebild Bakker lake is correlative and developed within more marginal shallow water proximal facies with excellent recovery of well-preserved spores with no AOM present in the lower lake. The D-C boundary is picked on the last occurrence of Retispora lepidophyta within an assemblage that has become largely Carboniferous in character and dominated by simple spores with Grandispora cornuta and Verrucosisporites nitidus. The upper lake at Rebild Bakker is similar to the assemblage at Stensiö Bjerg with local abundances of Botryococcus and Vallatisporites spp. 
been selected as representative of the deep and distal versus the shallow and proximal locations. This level of resolution contrasts with palynological studies of the D-C boundary in marine marginal settings where samples are often spaced on a metre to tens of metres scale to locate the boundary. In addition, these marginal marine sections have rarely been sampled at high resolution across the actual boundary. Other wellknown sections, for example in Belgium (Prestianni et al. 2016) and Poland (Filipiak and Racki 2010), have often proved to be palynologically barren in the vicinity of the boundary. This is because the sediments change to carbonates, not conducive to palynological preservation, forced by the continuing post-glacial transgression. This means that we miss the detail of how palynology might inform us as to the cause of the extinction. Five-gram rock samples were palynologically processed by standard techniques with $37 \% \mathrm{HCl}$, followed by $60 \% \mathrm{HF}$ and then decant washed to neutral followed by sieving at $15 \mu \mathrm{m}$. Neoformed fluoride removal was by a single treatment in hot $37 \% \mathrm{HCl}$ followed by rapid dilution and resieving. No oxidation methods were employed and AOM removal was using a Sonics and Materials ultrasonic probe (15 s) followed by resieving. Palynological residues were mounted in Elvacite 2044TM. Sample and slide numbers are provided in the relevant figure captions together with stage coordinates and England Finder references for Olympus BHS313 microscope No. 210685 in the School of Ocean and Earth Science, University of Southampton, e.g. RB-17-10 (1) (119.0, 10.5; R18-4). TOC and calcite was measured on a Carlo-Erba EA-1108 elemental analyser with an analytical precision better than $0.2 \%$. Organic matter $\delta^{13} \mathrm{C}$ analysis was by Iso-Analytical Ltd.

\section{The Stensiö Bjerg D-C boundary section}

The Obrutschew Bjerg Formation on Stensiö Bjerg (Fig. 2) is relatively thin $(3-5 \mathrm{~m})$ and includes two separate lake cycles. The lower lake is characterised by a basal interval of grey mudstone succeeded by $60 \mathrm{~cm}$ of interbedded mudstone and limestone with abundant desiccation cracks of lacustrine origin. Above this is a bed of organic-rich black mudstone with an increasing TOC $\%$ content that peaks at $21 \%$. Within this interval AOM (Fig. 4n) dominates the organic matter such that palynomorphs are very rare and restricted to simple spores with walls that are damaged by diagenetic growth of pyrite. The two lake cycles are symmetrical and climate driven from arid to permanent lake and then back to arid. Given the location of the section in the middle of the Old Red Sandstone Continent and in the southern hemisphere arid zone, these lakes will have been orbitally forced. The dominant orbital periodicity within the Late Devonian of East Greenland is precession (Astin et al. 2010; Olsen 1994) which implies that the two lake cycles had a combined duration of $40 \mathrm{kyr}$ and that the extinctions occupied a fraction of this time, i.e. at most a few thousand years. Within the AOM-rich lacustrine mudstone, there is a décollement level that also occurs in the Celsius Bjerg section and represents the syn-sedimentary downslope sliding of sediment masses within the extensional basin. These are often associated (Parnell et al. 1998) with over-pressure within the system and frequently occur in organic-rich beds during the initial stages of bitumen generation. The AOM-rich bed declines up section in TOC\% content and is replaced by a buff weathering carbonate rich interval that contains little to no organic matter and no preserved palynomorphs. Palynomorphs return in the upper lake together with two thinner intervals of AOM-rich organic matter. In the upper part of the upper lake, the organic matter becomes degraded to relict assemblages of dark phytoclasts. This is the result of either weathering (burn down, e.g. Kodrans-Nsiah et al. 2009) contemporary with the overlying calcrete that represents a sustained interval with a seasonally arid palaeoclimate. The other possibility is that it represents weathering down from the sub-Permian unconformity (Marshall et al. 2019a) that occurs some $3 \mathrm{~m}$ higher in the section.

Palynology of the D-C boundary section on Stensiö Bjerg

In general, the majority of the 150-m thick Stensiö Bjerg Formation has a low diversity palynological assemblage (Figs. 3 and 4, range chart as Fig. S3 in Marshall et al. 2020) that was dominated by Retispora lepidophyta and Diducites spp. Also present were many well-known latest Devonian spores including Auroraspora spp., Endoculeosporites gradzinskii, Tumulispora rarituberculata, Grandispora cornuta, Grandispora echinata, Raistrickia spp., Tergobulasporites immensus, Retispora macroreticulata, Rugospora radiata, Cyrtospora cristifer, Knoxisporites concentricus, Knoxisporites triangularis, Claytonispora rarisetosa and Retusotriletes spp.

Fig. 3 Spores and an alga from the D-C boundary sections in East Greenland. a Retusotriletes incohatus RB-17-50 us (124.0, 7.0; V23-2). b Claytonispora rarisetosa M5743 (109.5, 14.1; O8-2). c Verrucosisporites nitidus Sten 23.5 (138.8, 10.1; S38-1). d Apiculiretusispora fructicosa M5473 (135.0, 18.7; J35-1). e Knoxisporites literatus RB-17-11 (2) (137.1, 13.2; O37-3). f Tumulispora rarituberculata M5473 (125.7, 16.9; L25-2). g Verrucosisporites oppressus RB-17-10 (112.0, 16.4; L11-3). h Diducites mucronatus RB-17-45 (140.8, 20.6; G41-1). i Diducites versabilis RB-17-45 (138.0, 22.1; N22-3). j Diducites versabilis RB-1747 (122.7, 14.6). k Endoculeospora gradzinskii M5861 (121.1, 10.0; S202); I Rugospora radiata OB-1 (126.7, 14.8; N26-2); $\mathbf{m}$ Rugospora radiata RB-17-48 (129.0, 12.1; P28-4); n Indotriradites explanatus RB-17-11 (2) (114.0, 10.0; S13-1). o Retispora macroreticulata RB-17-43 (139.3, 13.7; O39-4). p Grandispora uncata OB-6 (136.2, 11.2; R36-1). q Grandispora echinata RB-17-49 (119.0, 19.6; H18-2). r Spelaeotriletes obtusus RB-1710 (1) (119.0, 10.5; R18-4). s Retispora lepidophyta RB-17-10 (143.2, 15.8; M43-2). t Retispora lepidophyta RB-17-43 (135.4, 22.4; E35-2). u Botryococcus sp. RB-17-50 us (128.3, 10.4; R28-3). Taxonomic citations are on Appendix, Table 1 

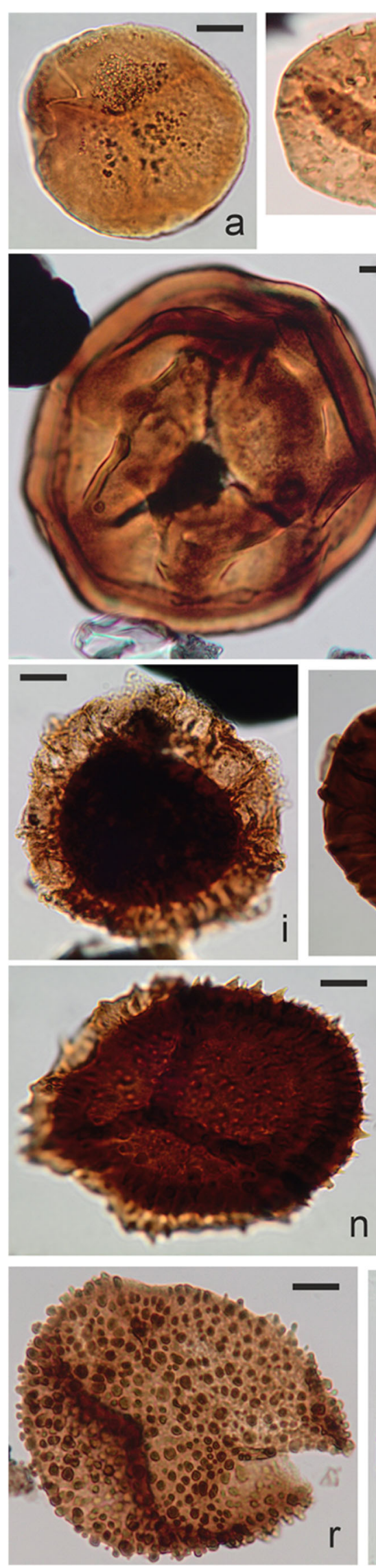
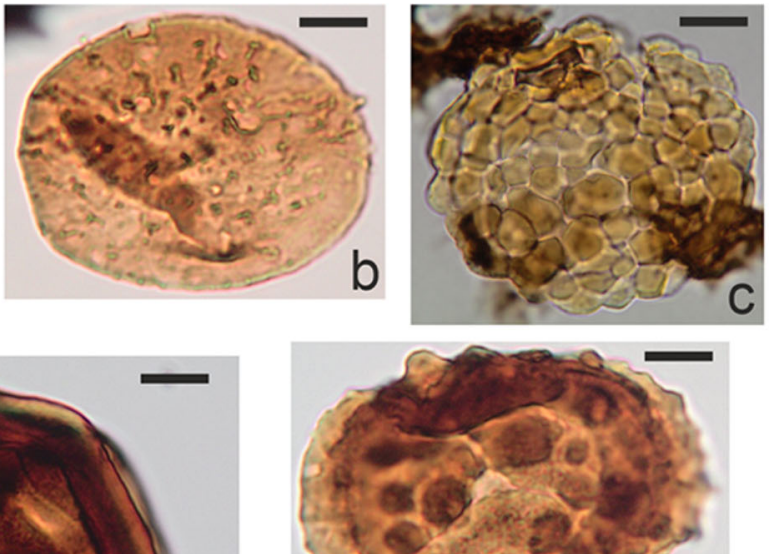

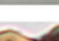
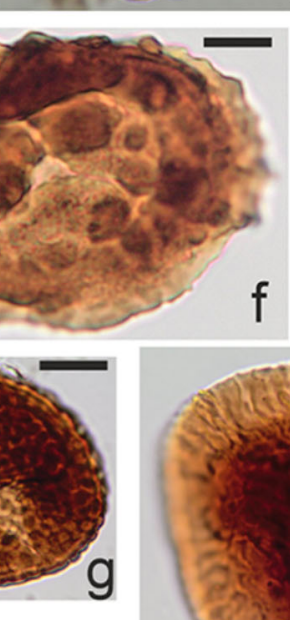

e

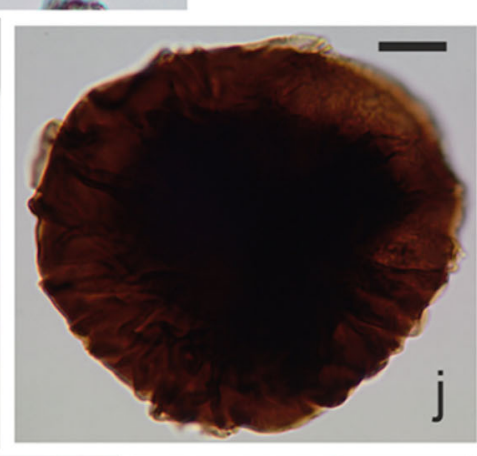

$n$
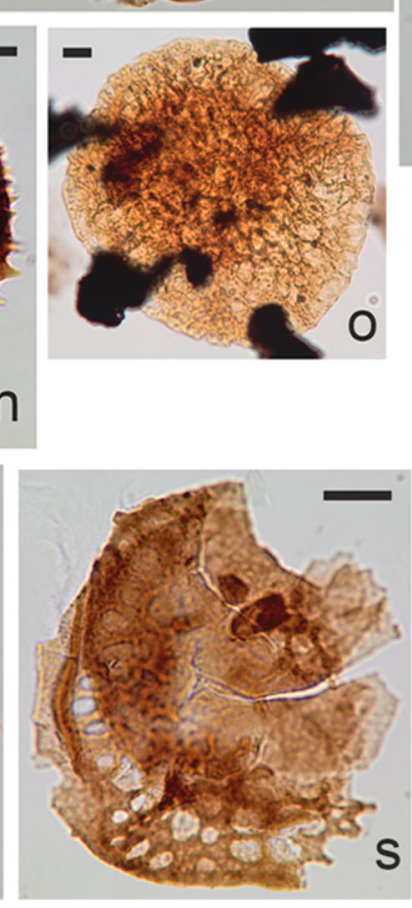
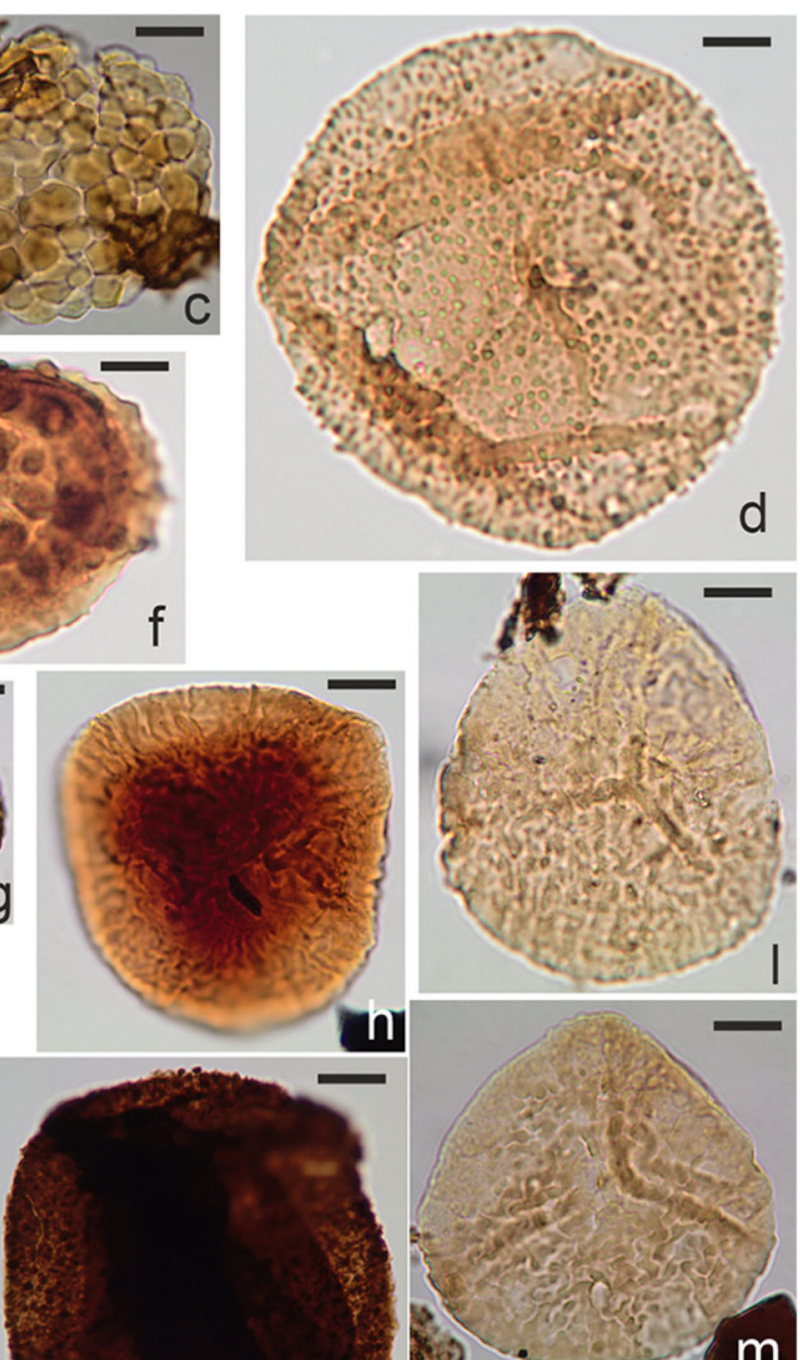

a.

$\mathrm{m}$
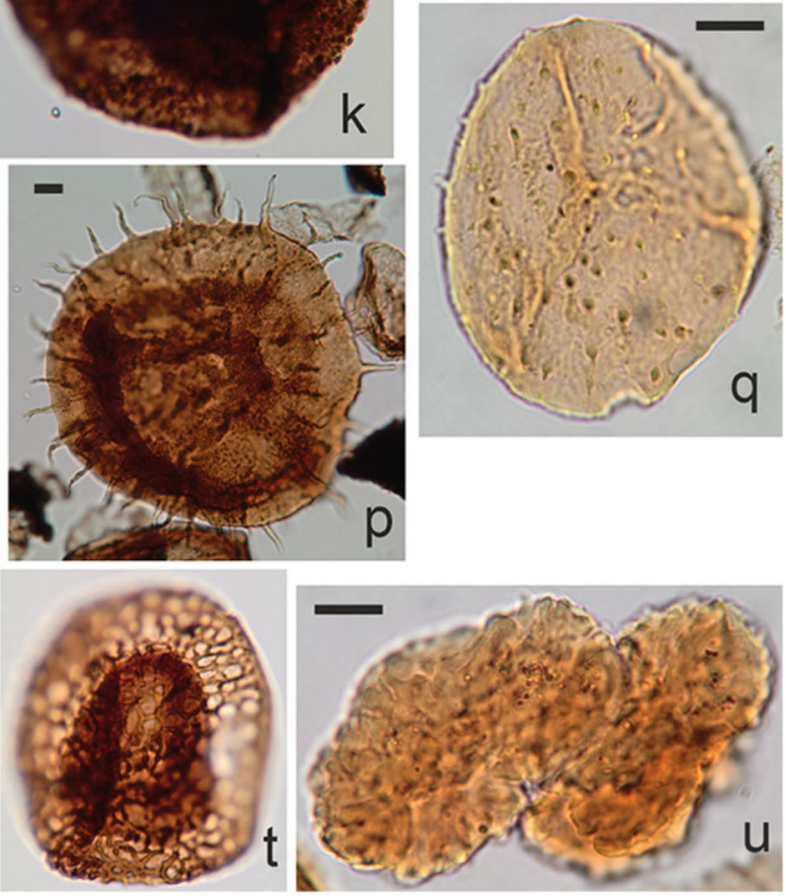

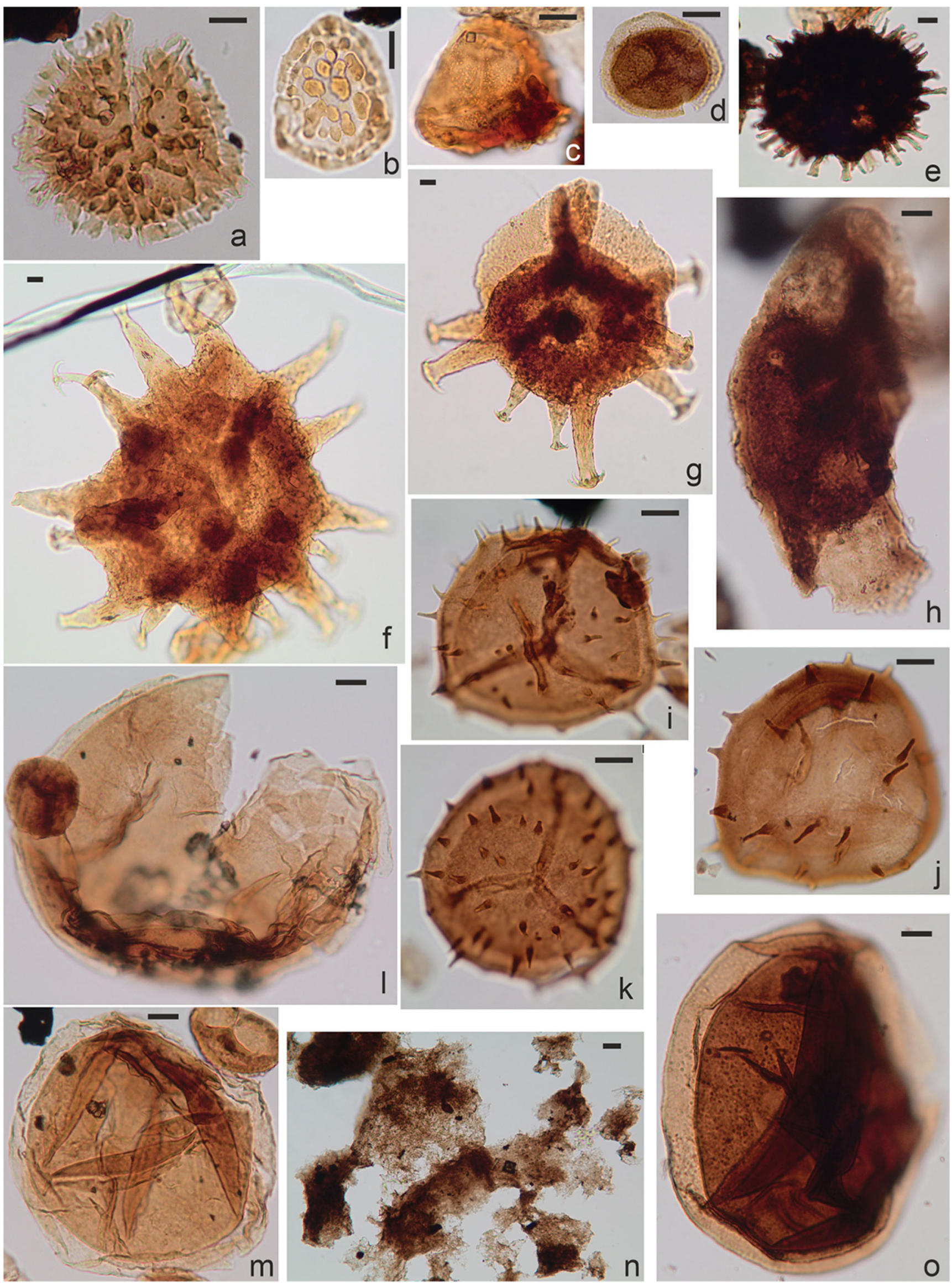
4 Fig. 4 Spores and pollen from the D-C boundary sections in East Greenland. a Vallatisporites pusillites Sten 42 (125.9, 10.0; S25-2). b Vallatisporites verrucosus Sten 43 (125.3, 15.6; M25-3). c Cyrtospora cristifer RB-17-49 us (123.0, 10.6; R22-4). d Auroraspora asperella RB-17-11 (1) (114.3, 16.4; L13-4). e Raistrickia variabilis M5839 (2) (128.4, 11.7; Q28-3). f Ancyrospora sp. M5744 mega (130.0, 11.8; Q29-2). g Hystricosporites sp. M5744 mega (123.1, 20.2; G22-4). h Tergobulasporites immensus M5859 (125.7, 9.5; S25-3). i Grandispora cornuta RB-17-12 lc2 (130.2, 18.0; K30-1). j Grandispora cornuta RB-17-11 (2) (127.1, 14.9; N27-1). k Grandispora cornuta RB-17-12 lc2 (132.7, 15.6; M32-4). I Remysporites/ Velamisporites RB-19-9 (124.1, 21.6; F23-2). m Remysporites/ Velamisporites RB-17-9 (112.6, 11.6; Q11-4). n AOM, amorphous organic matter Sten 37 (144.8, 11.8; Q45-3). o Remysporites/Velamisporites RB-1712 (124.6, 19.0; H24-3). Taxonomic citations are on Appendix, Table 1

Immediately below the Obrutschew Formation (Fig. 2), the uppermost $10 \mathrm{~m}$ of the Stensiö Bjerg Formation is palynologically barren and dominated by sediments deposited within an arid environment including a stage III calcrete that represents an interval of sustained aridity. Spore recovery only reoccurs with the return of grey mudstones that define the base of the lower lake. These assemblages (Figs. 3 and 4) contain abundant Retispora lepidophyta, Apiculiretusispora fructicosa, Retusotriletes incohatus, Rugospora radiata, Indotriradites explanatus, Tumulispora rarituberculata, Claytonispora rarisetosa, Knoxisporites literatus, Grandispora echinata, Cyrtospora cristifer, Ancyrospora spp. and Diducites spp. This assemblage represents a high level of diversity with most of the latest Famennian spores that are known from Euramerica present within the assemblage. This high diversity is related to the flooding of the lower lake that brings persistent humid conditions into the basin. In the lowest sample, there is the first occurrence of Verrucosisporites nitidus that defines the LN spore zone (Turnau et al. 1994). This spore has an inconsistent first occurrence being absent from some D-C boundary sections and regarded as an ecozone (Prestianni et al. 2016). Clearly, its inception in East Greenland in the lower permanent lake was controlled by the onset of humid conditions rather than the differential transport "heavy spore" hypothesis of Prestianni et al. (2016). This same increase in spore diversity just beneath the D-C boundary is recorded (Higgs et al. 1993) from the Stockum II auxiliary type section in Germany where it is referred to as the $\mathrm{LN}$ transitional zone, herein the LN* zone after its notation on the Stockum logs.

The first palynological changes occur in the thin mudstone intercalations in the overlying limestone with the disappearances of Retispora lepidophyta (apart from a single specimen some $1.5 \mathrm{~m}$ higher in the section) and an increase of Verrucosisporites nitidus, Grandispora echinata and Raistrickia variabilis. Spores with bifurcate-tipped spines are represented by both Ancyrospora capillata and Hystricosporites sp. Inceptions in this interval include Grandispora uncata and Vallatisporites spp. The latter is a very distinctive genus that occurs earlier (e.g. Higgs et al. 1988) in many other latest Famennian sections. The spore assemblage then disappears into the AOM-rich interval. When spores reappear in the upper lake, the assemblage is dominated by Retusotriletes incohatus and Vallatisporites (Vallatisporites verrucosus and Vallatisporites pusillites). About four other spores that survive the extinction event (Convolutisporites major, Verrucosisporites oppressus, Knoxisporites literatus and Apiculiretusispora fructicosa) reoccur sporadically in the upper lake. Another eight species also survive but are absent from the upper lake reappearing in younger Tournaisian sections. Present in abundance for the first time is the extant chlorophyte alga Botryococcus that today blooms in standing bodies of oxygenated freshwater (Batten and Grenfell 1996). This is rare in palynological assemblages from the Mid Devonian but its occurrence in abundance in the upper lake marks the first record of what subsequently became a major component in post Tournaisian freshwater ecosystems. Above this stratigraphic level, the spore assemblages become reduced to degraded resistant phytoclasts.

A record of $\delta^{13} \mathrm{C}_{\mathrm{TOC}}$ has been made (Fig. 2) of the bulk organic matter from the Stensiö Bjerg samples. This shows a general trend from about -26 to $-30 \%$ o through the two lake intervals. A single sample at $4.4 \mathrm{~m}$ was expunged from the analysis as it contained mostly pyrobitumen that is presumed to have formed by the in situ generation of hydrocarbons from the high TOC AOM-rich samples. The uppermost samples with a positive trend are from immediately beneath the Permian unconformity where the organic matter was dominated by relict wood. So, this trend is probably not significant. There are two positive spikes at 5.4 and $7 \mathrm{~m}$. These samples were reanalysed but gave the same results. There appears to be nothing different about the organic matter in these samples. However, they both come at the onset of either AOM facies or Botryococcus rich organic matter. So, the answer to these isotope spikes probably lies through compound-specific biomarker analysis of selected samples. The buff-coloured bed between the 2 lakes represents a time when the system either dried out or became a closed carbonate system and has 3 samples without organic matter at its maximum development. However, the $\delta^{13} \mathrm{C}_{\mathrm{TOC}}$ value trends to a less negative value below this as the lake became a closed system or dried out. There are many records of $\delta^{13} \mathrm{C}_{\text {carb }}$ through marine shelf sections at the D-C boundary. These are summarised in Kaiser et al. (2016) which also includes marine $\delta^{13} \mathrm{C}_{\mathrm{TOC}}$ records. These records show a positive excursion coincident with the base of the Hangenberg Black Shale which is below the level of the lower lake on Stensiö Bjerg. The interpretation of the negative excursion from the Stensiö Berg section is that it represents the upper part of this positive excursion and the return to stable values. Lakes can be somewhat equivocal for isotope records as they are often closed system for part of the cycle and only reflect a local signal. However, the size and volume of the East Greenland D-C boundary lakes placed then within a system that remained "fresh" that together with the 
arrival of the new fish (palaeoniscid and a shark) implies significant water throughput and that the system is in general open, connecting to the sea and hence provides a "global" $\delta^{13} \mathrm{C}_{\mathrm{TOC}}$ signal.

\section{The Rebild Bakker D-C boundary section}

This section is of particular significance as it is the locality where the malformed spores have been recorded (Marshall et al. 2020). The locality is on the side of a steep ravine and although well exposed is difficult to photograph on an outcrop scale. As in the Stensiö Bjerg locality, there are two lakes present within the section. These lakes are within a sequence of immature fluvial sandstones interbedded with mudstones that represent the floodplain environment. Figure 2 shows these two lakes. The lake flooding starts with the sandstone showing undulating parallel lamination that represents reworking of fluvial sediments under the shallow but expanding lake. The base of the lacustrine mudstone starts with a $5-\mathrm{cm}$ bed of impure nodular limestone. The main lake development is represented by a 48 -cm thick interval of mudstone interbedded with numerous siltstone beds individually about $1 \mathrm{~cm}$ thick. The upper layer of the mudstones contains numerous desiccation cracks showing that the lake bed dried out. Above this, there are a number of thin bedded sandstones again representing lacustrine reworking of fluvial sandstones. These parallel laminated sandstones continue to the base of the upper lake which starts with $30 \mathrm{~cm}$ of green homogenous coarse siltstone. This upper permanent lake is only $20 \mathrm{~cm}$ thick of black mudstone with a single interbed of finegrained sandstone. In contrast to the lower lake, this black mudstone contains AOM that represents microbial production from the lake preserved under a stratified water column. The double lake cycle then terminates in parallel laminated sandstone and is succeeded by a thick interval of mudstone variously purple and green in colour including fabrics characteristic of palaeosols.

\section{Palynology of the D-C boundary section on Rebild Bakker}

This palynological record from Stensiö Bjerg (Fig. 1) only shows that the D-C boundary occurs at some point within, either the AOM-rich interval or the barren palynological samples in the lowest $30 \mathrm{~cm}$ of the upper lake. Importantly, this boundary can be picked in the correlative lower lake section on Rebild Bakker. Here the section was deposited in shallow water, and was more proximal and without AOM. Therefore, the spore assemblages are well preserved, abundant and diverse. The assemblage from the base of the lake and throughout the section lacks any of the species that go extinct at the D$\mathrm{C}$ boundary such as bifurcate-tipped spores, Rugospora and Diducites. However, there are rare specimens of Retispora lepidophyta at $9 \mathrm{~cm}$ above the base of the lake bed. This matches the isolated last occurrence of $R$. lepidophyta in the Stensiö Bjerg section and is used to correlate the two sections and define the top of the Devonian. The D-C boundary is defined here using the last occurrence, i.e. extinction of $R$. lepidophyta. The current GSSP section at La Serre is present within entirely carbonate sediments with never any possibility of palynomorph preservation. So, the boundary pick for the last occurrence of $R$. lepidophyta is from clastic-dominated sections in Germany notably Stockum II (Higgs et al. 1993; Clausen et al. 1994) and Hasselbachtal (Higgs et al. 1993; Higgs and Streel 1994) where the LN* to VI zonal boundary occurs between the Lower and Upper Stockum Limestones. The spores are present in the mudstones with the ammonoids and conodonts only in the limestones. So, this places the last R. lepidophyta (Higgs et al. 1993) in a mudstone $80 \mathrm{~cm}$ beneath the Upper Stockum Limestone which is the level at which the first Carboniferous conodonts and ammonoids appear (Becker et al. 2016).

The palynological assemblage in the lower lake is dominated by Grandispora cornuta, Retuses incohatus, Verrucosisporites nitidus, Grandispora echinata, Auroraspora asperella, Knoxisporites literatus, Tumulisporites rarituberculatus and Spelaeotriletes obtusus. Apart from the rare occurrence of Retispora lepidophyta, this assemblage can be attributed to the VI spore zone. This demonstrates that the deeper AOM-rich part of the lower lake is of proven VI spore zone age when it transgresses into a proximal section. Therefore, on Stensiö Bjerg, the base of the AOM-rich interval is placed at the base of the VI spore zone and hence marks the base of the Carboniferous. Many of the spores present are dark pigmented. In addition, Grandispora cornuta is very abundant with the majority of specimens being malformed, notably in the spines. The degree and relative abundance of these malformed spores increase to the midpoint of the bed. Also present are malformed specimens of Verrucosisporites nitidus. Illustrations of multiple specimens of these malformed spores are in Marshall et al. (2020).

The upper lake bed on Rebild Bakker has a distinctly different assemblage that includes a significant abundance of Retusotriletes incohatus and Verrucosisporites nitidus. In addition, Vallatisporites has local first occurrences as both $V$. pusillites and $V$. verrucosus. Botryococcus is also abundant in some samples. It resembles the upper lake palynological assemblage from Stensiö Bjerg except that it was somewhat more diverse. In a single sample (Fig. 4j), there are a few dark coloured specimens of Diducites versabilis with a separate single example of Rugospora radiata (Fig. $4 \mathrm{~m}$ ). These are above their anticipated extinction level. The lower lake represents a major lacustrine flooding event when the lake will have transgressed onto its fluvial margins and potentially a coincident margin against basement. When the lake dried out, these marginal lacustrine deposits will have been above the normal 


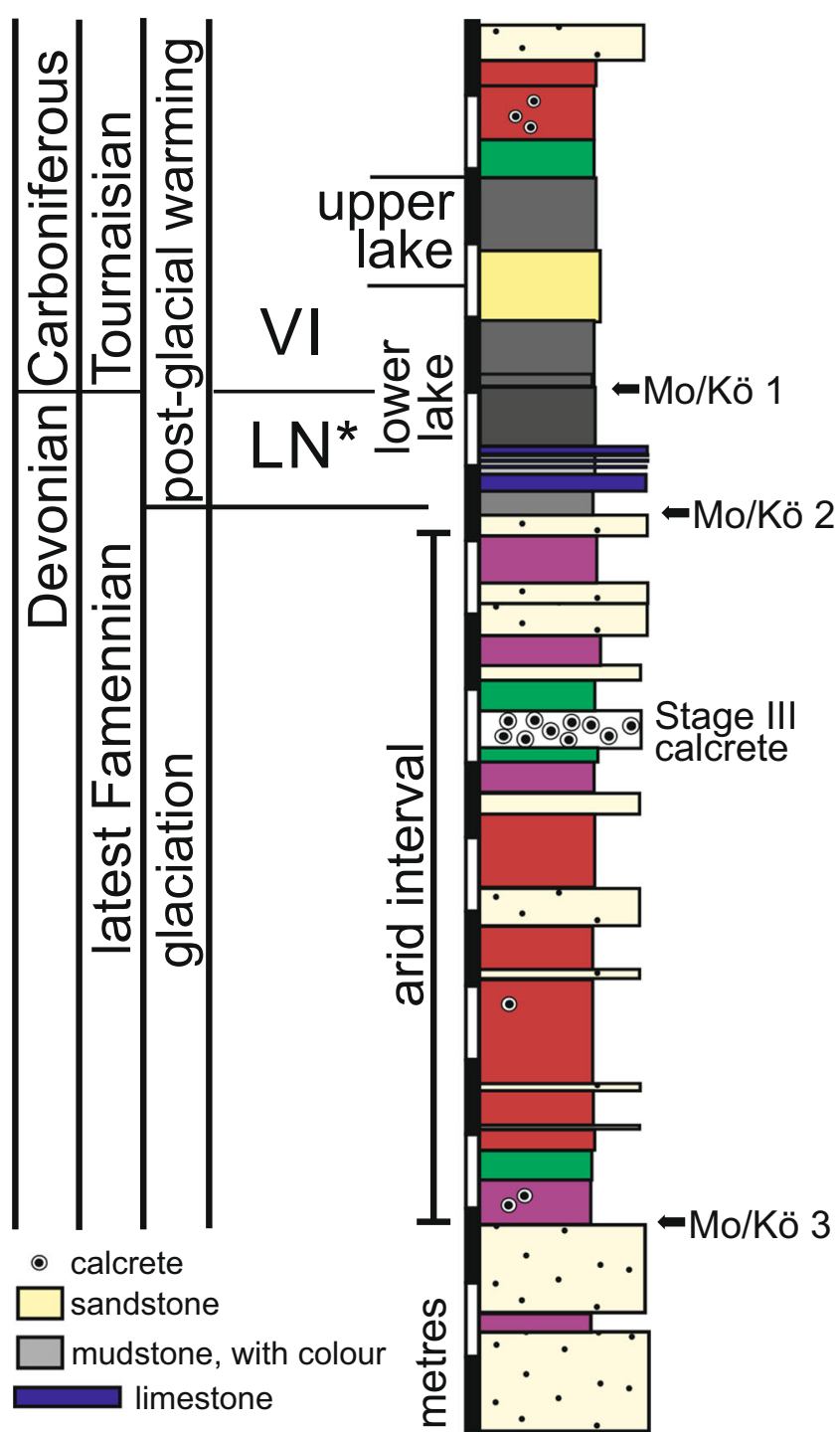

Fig. 5 Sedimentary log from Stensiö Bjerg, East Greenland. Identified are the likely levels for the three Montpellier/Köln criteria for defining the D-C boundary. Mo/Kö 1 is the level of terrestrial plant extinctions as revealed by the coincident last occurrences of Retispora lepidophyta, Ancyrospora spp. and Rugospora radiata. Mo/Kö 2 is the top of the major regression above the Hangenberg Sandstone and the start of the major radiation. This is the level currently chosen for the redefined GSSP. In East Greenland, this level is placed at the start of warming in the terrestrial environment that marks the ending of the terminal Famennian glaciation and glacially forced regression. Mo/Kö 3 is the base of the arid interval interpreted as the start of the terminal Famennian glacial cycle where the Hangenberg Black Shale has been interpreted as the adjustment of the sedimentary system to a lower sea level. Log modified from Marshall et al. (2020)

sediment accommodation level and hence become extensively eroded releasing their palynomorphs and with it the potential for reworking. So, there is a distinct possibility these younger occurrences represent reworking (hence the colour) or relict occurrences from a few population that briefly survived the mass extinction (dead clades "cloning").

\section{The Greenland D-C boundary and the Montpellier/Köln Criteria}

Initially, three possible boundary levels (Fig. 5) for the redefinition of the D-C boundary were discussed in the Montpellier and Köln meetings:

1. Base of kuehni Zone/basal sulcata Zone and coastal plant extinction (Mo/Kö 1)

2. Base of kockeli Zone, beginning of radiation and top of major regression (top of the Hangenberg Sandstone, HSS) and end of mass extinction (Mo/Kö 2)

3. Mass extinction level ("big six mass extinction") and base of Hangenberg Black Shale (Mo/Kö 2)

Criterion 1 (Fig. 5, Mo/Kö 1) as regards terrestrial environments, the so-called coastal plant extinction (Fig. 5) is the clearly defined level. The name "coastal plant" refers to erroneous view that the Retispora lepidophyta plant was restricted in the coastal environments. Its presence in abundance (60\%) in East Greenland some $1000 \mathrm{~km}$ from the sea demonstrates that it was not restricted in this way. Figure 2 shows the pattern of extinction of spores across the boundary. At Stensiö Bjerg, Ancyrospora spp. and Rugospora radiata occur in most samples then disappear at the base of the AOM-rich interval. Retispora lepidophyta was abundant but then abruptly lost when the lake started to flood, apart from a single specimen at the same level as the last Ancyrospora and Rugospora radiata. The lake margin section at Rebild Bakker is within a section of fluvial sandstone so palynological assemblages are not common, the closest being $13 \mathrm{~m}$ below the lower lake. At the boundary, palynological assemblages are only present in the lacustrine mudstones. In the lower lake, there is no AOM so that spores are abundant, diverse and well preserved. There are rare specimens of Retispora lepidophyta in one of the lowest samples but Ancyrospora spp. and Rugospora radiata are both absent. Within this section, the LN to VI boundary is picked at the extinction of $R$. lepidophyta and shows that the bulk of this lake bed is earliest Carboniferous in age. Therefore, the same lower lake lacking spores at Stensiö Bjerg is also Carboniferous in age. In addition, the AOM-rich interval is not concealing any range extensions of Devonian spores. These spores all become extinct at the base of the lake below the AOM-rich interval. Hence, the extinction of $R$. lepidophyta with these other taxa makes a consistent boundary definition. If the lower lake represents a single precessional cycle, then these extinctions occur within a few thousand years.

The recognition that the kill mechanism for the terrestrial extinctions was a burst of UV-B radiation gives us a new rationale for defining the D-C boundary. This is because we now have a viable kill mechanism that was brief and hence we know, and have shown from the palynological range terminations, that the terrestrial extinction was not drawn out in time. 


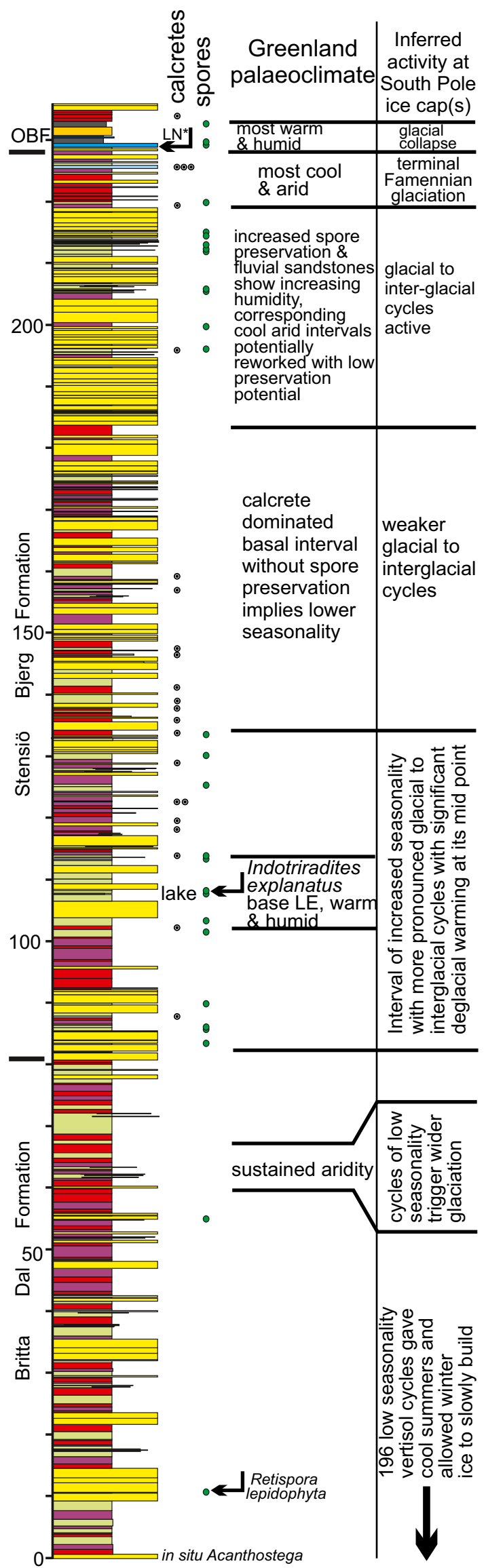

Fig. 6 Stratigraphic log from the upper Britta Dal through the Stensiö Bjerg and Obrutschew Formations (OBF) from Stensiö Bjerg (the mountain). The distribution of sandstones, mudstone colours, calcretes, spores and lakes reveals a proxy record of palaeoclimate. The uppermost part of the Britta Dal Formation is the top of a significant and monotonous stack of vertisols representing cool arid conditions and lower atmospheric circulation. This combination is a mechanism by which glacial ice can build up as the summers are too cool to melt the accumulation of winter snowfall from the previous year. The upper part of the Britta Dal Formation has an interval of sustained aridity that may have generated a more widespread glaciation. The inception of Retispora lepidophyta into otherwise palynological barren strata occurs $10 \mathrm{~m}$ above the well-known in situ occurrence (Blom et al. 2005) of Acanthostega. The next interval at the base of the Stensiö Bjerg Formation is a combination of increasing seasonality expressed as cooler aridity with calcretes and palynological recovery reflecting warmer and wetter times. At the midpoint of the interval, a permanent stratified lake developed that represented a significant warming and implied a major deglaciation. This is succeeded by an interval of weaker seasonality. Towards the top of the formation, seasonality increases again with an increasing frequency of spore preservation and sandstones representing warmer and more humid intervals. Above this, there is a sustained interval of aridity including a stage III calcrete. This is interpreted as the far-field expression of the last and most intense of the latest Famennian glacial cycles. Above this, there is the warming and the formation of the deep wide stratified lake of the Obrutschew Formation

This makes it a time plane and an ideal level for a GSSP definition. In this way, it is identical to defining the $\mathrm{K} / \mathrm{Pg}$ boundary based on the combination of the Iridium spike and extinctions. It also explains the instability of conodont lineages and our ability to use them for earliest Carboniferous zonation as UV-B penetration into shallow waters causes continued mutations.

Criterion 2 (Mo/Kö 2, Fig. 5) can be inferred from the palaeoclimatic motif. The end of the regression will be the start of the sea level rise driven by the collapsing ice sheets. This was expressed in East Greenland by the climatic warming that melts the ice and was bringing the increased monsoon-driven rainfall into the centre of the ORS Continent. So, this will be at the approximate level of the return of palynological preservation with the diverse $\mathrm{LN}^{*}$ palynological assemblage. This was the level chosen at both the Montpellier and Köln meetings for the redefinition of the boundary. However, given the discovery that the extinction was caused by a brief UV-B burst, it would now seem essential to reserve this decision and reconsider criterion 1.

As regards identifying criterion 3 (Mo/Kö 3, Fig. 5) i.e. the base of the Hangenberg Black Shale (HBS) and the marine mass extinction level, there is no direct palynological evidence for this level from East Greenland. However, if, as concluded by Bábek et al. (2016) that the Hangenberg Black Shale marks readjustment of low latitude sea levels to the terminal Famennian glaciation, then it can recognised in the East Greenland climatic record. Marshall et al. (2020) (Fig. 5) demonstrate a 9-m thick arid interval below the lower lake including a stage III calcrete that represents a significant time gap. 
So, we can recognise this as correlative to the HBS level but not uniquely defining or identifying it.

\section{The Greenland latest Famennian as a far-field glacial record}

There is a significant and continuing debate as to the duration of the latest Devonian glaciation(s). This is important for interpreting latest Devonian extinctions in the context of changing palaeoclimate. In particular, the glaciations are an important part of the discussion as to the state of the Earth System both in general (e.g. Kaiser et al. 2016) and for the initial phase of extinctions coincident with the Hangenberg Black Shale (Marshall et al. 2020). The Gondwana glacial records (reviewed in Lakin et al. 2016) are now extensive, occurring at multiple localities across South America and in the eastern USA. The majority of the occurrences are diamictites that occur within marine sections and represent the deposits that formed during glacial collapse when melting ice dispersed to lower latitudes. When securely dated, most of these records are very latest Famennian in age and represent the terminal glaciation and its collapse at the DevonianCarboniferous boundary. This is normal for any series of glaciations as the terminal glacial collapse deposits are most likely to be preserved. However, there is evidence in eastern Bolivia (Wicander et al. 2011) for a longer record of glaciation with a succession of diamictites encompassing the LL to LN spore zones. These diamictites are transitional from non diamictite mudstones of VCo age that terminate a contiguous section of the Iquiri Formation (Troth et al. 2011). Significantly, the diamictite succession in eastern Bolivia includes a large dropstone of non-glacigenic sandstone (with its interbedded minor mudstone intercalation yielding an LN spore zone age) that shows striking soft sediment deformation. Wicander et al. (2011) interpreted this dropstone as the glacial deformation of unconsolidated sediment that was then incorporated as a frozen block into the melting ice. The assignment of an LL to LN age for the diamictite sequence has been challenged by Streel et al. (2013) who regard the succession as entirely LN zone in age, i.e. the product of a single glaciation. However, further information (Ettensohn et al. 2020) is now available on the age dating of diamictites from the eastern USA. This shows the presence of diamictites in both Maryland and Pennsylvania of LE spore zone age. In Pennsylvania, these LE diamictites are separated from younger occurrences by normally bedded sediments. Therefore, although we cannot yet resolve the separate glacial cycles within Gondwana, we know that glacial sediments characterise the latest Famennian, generally coincident with the range of Retispora lepidophyta.

The location of the East Greenland Devonian Basin at $15^{\circ}$ palaeo south and within the continental interior of the Old Red
Sandstone Continent places it in a similar position to modern day Lake Chad, i.e. at the margin of the monsoon system (Ehrmann et al. 2017). Like Lake Chad, it can provide us with a far-field proxy glacial record with aridity representing the cool conditions of a weak monsoon and the warmer humid intervals the more active monsoon driven by increased insolation. In East Greenland, the Wimans Bjerg and Britta Dal Formations (Figs. 1 and 6) contain $196 \mathrm{red} /$ purple (arid) to green (less arid) vertisol cycles (Astin et al. 2010). Vertisols are a distinctive palaeosol that forms under the specific climatic conditions of low seasonality and sustained aridity. Time series analysis suggests a strong precessional signal (at $18 \mathrm{kyr}$ ); therefore, the 196 cycles occupy some 3.5 million years of geological time with the upper $75 \mathrm{~m}$ of the Britta Dal Formation in the LL spore zone based on the inception into palynologically barren strata of Retispora lepidophyta. The presence of a monotonous stack of vertisol cycles for 3.5 myr reveals that the prevailing monsoon system was weak, and therefore unable to pull significant moisture into the centre of the ORS Continent. In such low insolation conditions, the Earth would be cool and arid and importantly with cool summers that were insufficiently warm to melt the previous winter's snowfall. Such cool summers are required for the build-up of continental scale ice sheets. At the top of the Britta Dal Formation, there is a group of red vertisols without any intervening green vertisol component and representing an interval of sustained aridity. Comparisons with the sudden spread of Oligocene ice (Coxall et al. 2005) suggest that this longer episode of aridity could be the trigger that tipped the Earth System into a full icehouse world.

The overlying Stensiö Bjerg Formation shows a strong contrast as the palaeosols change from vertisols to aridisols (characterised by calcrete nodules) and these represent increased aridity. Interbedded with these calcretes are grey and green mudstones containing organic matter together with fluvial sandstones as the river discharge became strong enough to transport sands out on the distal terminal fan environment. These drab-coloured sediments indicate humid conditions. This shows that the climate system has significantly increased seasonal activity with wetter wet seasons and drier dry seasons.

Spore correlations show us that this palaeoclimatic change was broadly coincident with the presence of ice in Gondwana and the eastern USA. The duration of this polar ice has been variously interpreted as being as long as the estimated duration of the Strunian at 3 myr (Wicander et al. 2011) or a fraction of this at $0.5 \mathrm{myr}$ (Ettensohn et al. 2020). But, as with any glaciation, there would have been longer lived permanent ice at the South Pole with a superimposed pattern of glacial to inter-glacial cycles that reached to lower latitudes and were potentially driven by precession. It is this pattern of higher frequency events that we are recognising at the D-C boundary in East Greenland. The remarkable sequences of vertisols in the Wimans and Britta Dal Formation give a good proxy for 
aridity within the sequence. But once the seasonality increases in the Stensiö Bjerg Formation, the presence of sandstones and calcretes means that the now heterolithic succession is less easy to interpret with thicknesses not representative of time and with an increased probability of gaps within the sequence.

In the lower part of the Stensiö Bjerg Formation, there was a more humid interval that at its midpoint includes sediments with AOM, a TOC maximum of $2.6 \%$ and hence a stratified permanent lake system. This lake includes the inception of Indotriradites explanatus that defines the base of the LE spore zone and marks a brief interval when spores more typical of humid conditions were able to migrate into the basin. This lacustrine flooding was similar to the Obrutschew Formation lake but a magnitude lesser in scale. It represents a mid latest Famennian episode of warming (potentially a more significant deglaciation) separating an earlier longer interval of glacial to inter-glacial cycles.

In the upper part of the Stensiö Bjerg Formation, there was a second interval when indicators of both cool (calcretes) and humid (grey-green sediments with organic matter) reoccur. This includes the intense cooling (Fig. 5) associated with the extensive spread to lower latitudes of the terminal Famennian glaciation immediately succeeded by the equally intense warming of the Obrutschew Formation lake at the D-C boundary.

So, what we can envisage is a long-lived ice cap(s) on polar Gondwana that took significant time to accumulate. Throughout its existence, this ice cap was subjected to a series of orbitally driven glacial and inter-glacial cycles controlling ice advance and partial retreat. The retreating "inter-glacials" brought characteristic diamictites into lower latitude marine environments. There was no distinctive isolated terminal Famennian glaciation, and the ice was always there. This was just the most significant of the glacial cycles and its collapse produced the most widespread diamictite deposits.

There is supporting evidence (Pas et al. 2018) for these timings and palaeoclimatic interpretations from marine mudstones of the Illinois Basin, USA that is at $\sim 35^{\circ}$ palaeo south. Time series analysis of the magnetic susceptibility signal reveals the pattern of long and short eccentricity cycles. This shows a long ( $\sim 2 \mathrm{myr})$ interval of low amplitude signal in the late Famennian similar to that shown by the Wimans Bjerg and Britta Dal Formation vertisol cycles. This was succeeded by a shorter interval of much higher amplitude cycles for the last two long eccentricity cycles (i.e. $800 \mathrm{kyr}$ ) of the latest Famennian. Unfortunately, their sample resolution was insufficient to detect precession cycles.

\section{D-C boundary plant extinctions}

It has long been accepted (e.g. Edwards et al. 2000) that there were significant changes in both plants and their dispersed spores at the Devonian-Carboniferous boundary. Recently there have been contributions that include quantitative analysis of data across the Devonian-Carboniferous boundary. That of Silvestro et al. (2015) was based on Bayesian analysis of origination and diversification rates through all the Big 5 mass extinctions. However, the discussion on Devonian vascular plants focused on the Late Devonian Frasnian-Famennian or Kellwasser Event. However, their data analysis of the Famennian and Tournaisian stages showed a significant decline occurred in both the rate of originations and extinctions. This gives a very low net diversification rate in the Tournaisian. Subsequently Cascales-Miñana (2016) compiled a record of Ordovician-Mississippian diversity from both megafossil plants and spores with the data taken from the Paleobiology Database (PBDB) and selected publications. This showed a trend of increasing diversity across the Devonian-Carboniferous boundary and hence the conclusion was inferred that there was no D-C boundary terrestrial biotic crisis in land plants and that extinctions were solely restricted to the marine realm. The drawback with such an analysis is that it sums and contrasts the diversity from within two long stages (Gradstein et al. 2020), the Famennian being some 12 myr in duration and the Tournaisian at 12.6 myr. In particular, the Tournaisian includes the recovery of diversity from the D-C boundary mass extinction. It must also be noted that there are very few comparable plant assemblages that are latest Famennian or earliest Tournaisian in age. So, the type of analysis of Sallan and Coates (2010) for fish and tetrapods where the assemblages were arranged in a time sequence across the boundary is not yet feasible.

In contrast, the global record from the palynological studies that cross the boundary (e.g. Higgs et al. 1988; Van Veen 1981; Gao 1989) shows significant extinctions to occur in a number of major clades and that these are concentrated immediately below the boundary. The recovery microflora (VI spore zone) being low diversity and dominated by spores that are morphologically simple. In addition, a number of the more complex spores with latest Famennian inceptions (Claytonispora, Indotriradites, Knoxisporites, Raistrickia) were sporadic to absent from this earliest Tournaisian VI microflora. So, the D-C boundary as well as including extinctions of entire clades includes a major disruptive event to otherwise successful elements within the flora. This pattern of extinction was discussed by Traverse $(1988,1990)$ who noted the comparative resilience of plant taxa to extinctions on account of their ability to propagate asexually and resilience to high levels of habitat disturbance. Clearly, as now, some Late Devonian plants were less resilient to the particular kill mechanisms and became extinct. This was seen in the loss of distinct clades such as all plants with bifurcate-tipped spores. Many floral elements survive but reassemble as a very different flora with the dominant larger plants being lycopods rather than progymnosperms. As regards the duration of the 
recovery microflora, in the Tournaisian of the Scottish Borders, the VI spore zone (Marshall et al. 2019b) occupies some $70 \mathrm{~m}$ of section within $520 \mathrm{~m}$ of Tournaisian strata (Millward et al. 2019). So, this is approximately 1.5 myr based on a 12.6-myr duration for the Tournaisian (Gradstein et al. 2020). In order to understand better the plant extinctions at the D-C boundary, it is opportune to consider what we know or can hypothesise as to the palaeobiology and character of these extinct clades.

\section{?Retispora lepidophyta}

This is the most conspicuous extinction at the D-C boundary. Retispora lepidophyta is a distinctive small spore that has a rapid inception at the base of the latest Famennian through which it then occurs in abundance (often in excess of $60 \%$, Maziane et al. 2002; Marshall et al. 2020). It has a distinctive morphology with an outer wall layer (exoexine) that is perforated with small holes or fovea. Its occurrence is global with multiple records (Streel and Marshall 2006) from North and South America, North Africa, Europe, Siberia, Greenland, Svalbard (Bjørnøya or Bear Island), China, Australia and Antarctica (pers. obs.). Hence, it occurs in every Devonian palaeolatitude that has land. The spore changes in its morphology through its range becoming smaller in diameter (Maziane et al. 2002) and along with other spores shows malformation (Prestianni et al. 2016) in the upper part of its range. As regards palaeoenvironment, it was not a spore that was only characteristic of downstream swamp margins (Maziane et al. 2002) as it ranges from coastal margins to interior dryland basin. It also does not represent a distinct lepidophyta flora (Kaiser et al. 2016) but is instead a conspicuous component within many different floras. Its global distribution and environmental tolerance enable us to sketch out a likely scenario for the, as yet, completely unknown morphology and mode of life of the parent plant. The high spore production, potentially a superproducer and the absence of any distinctive co-occurring megaspores, strongly suggests it was homosporous. A conclusion substantiated by its global distribution (Marshall 1996) as the existence of a larger megaspore would limit its ability to cross Devonian seaways. In the many localities with high abundances of Retispora lepidophyta, there is no obvious or consistent megafossil plant that is without a spore affinity. However, there are often many plant fragments. This implies a small plant without substantive or permanent vegetative growth. All this points to a ruderal or weed lifestrategy characterised by a small, herbaceous plant that grows rapidly and with an enormous environmental tolerance. The caveat being that within the more arid conditions characteristic of the latest Famennian glaciation there may have been an arid and perhaps seasonal niche within most biomes. However, the surprise is that despite this enormous success in spreading globally across all palaeolatitudes and inhabiting every terrestrial sedimentary environment in addition to surviving all the vicissitudes of the latest Devonian glaciation, the Retispora lepidophyta plant then rapidly became extinct during the immediate post-glacial warming phase. Hence, it must in some way have been either peculiarly vulnerable and, in addition, was unable to survive vegetatively through the terrestrial crisis of the D-C boundary mass extinction. We can speculate that it was an annual or short-lived plant. In this instance, this would be a weakness if, for part of its life cycle, it only survived as spores or gametophytes and this would render it susceptible to extinction after a few seasons of difficult conditions. We can now understand this in the context of elevated UV-B radiation at the D-C boundary (Marshall et al. 2020). We know the plant was affected by UV-B as Prestianni et al. (2016) report malformed specimens from immediately below the boundary. So, a plausible explanation for its extinction would be that it was a small annual plant without strong vegetative growth and producing only sterile spores would rapidly make it extinct.

\section{The ?Diducites spore morphon}

The Diducites spore morphon (Van Veen 1981) includes spores that are characterised by three wall layers. The exoexine layer is unusual for Devonian spores in that it is enveloped in a thin wrinkled external perispore. All these layers are without sculpture. Diducites is an in situ spore of the "prefern" Rhacophyton (see discussion in Streel and Scheckler 1990) and is known from temperate coal layers from Virginia, USA where it forms a distinct coastal wetland flora but is also present together with Archaeopteris on the drier floodplains (Scheckler 1986). Greb et al. (2006) using the Red Hill tetrapod locality reconstructed a Devonian lacustrine wetland margin with an Archaeopteris forest and Rhacophyton as the scrubby understorey layer. Clearly, the continental interior environments in East Greenland are distinctly different to these examples but Diducites is common in the Stensiö Bjerg Formation, and in some samples, it is second in abundance to Retispora lepidophyta. This makes the plant a major component in the ecosystem and emphasises the recognition by Scheckler (1986) that it was, like many Devonian plants, very tolerant of different environmental conditions as it has been found in many different biomes. As a spore, it was also widely distributed across Euramerica so its extinction at the D-C boundary indicates the loss of a significant component in the Devonian flora. The zygopterid ferns, the group that includes Rhacophyton, do survive into the Carboniferous but had spores that were distinctly different (Balme 1995). Hence, Diducites and Rhacophyton did represent a distinct clade. 
Devonian spore genera with bifurcate-tipped spines_? Ancyrospora, ?Hysticosporites and ?Nikitinsporites

There is a very distinctive and diverse group of Devonian spores that all possess bifurcate spines. They originated in the latest Early Devonian, were particularly abundant in the Mid Devonian and continued through the Late Devonian to terminate at the D-C boundary.

Ancyrospora was particularly abundant in the Eifelian of Euramerica before the origination of the Archaeopteridalean progymnosperms when it dominated palynological assemblages (Marshall and Allen 1982) together with the aneurophytalean spore Rhabdosporites. Little is known about its affinities but the limited available evidence suggests Ancyrospora was produced by a lycopod. Spore associations (Marshall pers. obs.) from the Eifelian of Canning Land in East Greenland show a high abundance of Ancyrospora associated with Thursophyton, a herbaceous lycopod. In addition, evidence from comparative TEM ultrastructure (Wellman 2002) also indicates an affinity to the lycopods. Hence, they represent an, at times, major and diverse component within most Mid and Late Devonian floras.

Hystricosporites is, in some respects, similar to Ancyrospora but differs in lacking an extended equatorial flange and in its gross morphology was longer in body length than diameter. It tends to have a smaller number of longer more robust spines. There are frequently radial ribs on the contact face. It is less common in Devonian spore assemblages than Ancyrospora, usually only present as a minor component, although locally it can be abundant. As regards stratigraphic range, it reaches to the D-C boundary when it becomes extinct. Its affinities are unknown.

Nikitinsporites is the third genus of Devonian spores with spines that have bifurcate tips about which somewhat more is known as regards its affinities. The affinities of these cooccurring sporangia have been discussed by a number of authors (Chaloner 1959; McGregor 1969) who attributed them to the Isoetalean lycopods largely based on the co-occurrence (Nikitin 1934) of both Nikitinsporites and Archaeoperisaccus within morphological similar sporangia from a single locality at Petino, near Voronezh, Russia. Archaeoperisaccus had a Givetian inception but was particularly characteristic of the Frasnian but geographically restricted to northern Euramerica and Siberia. The stratigraphic range of Nikitinsporites is different from the presumed microspore as it extends into the Famennian and to the D-C boundary where it becomes extinct. The literature also includes a record (Richardson 1969) from the earliest Carboniferous. Usefully, the same range chart shows Nikitinsporites to co-occur in the Tournaisian with Retispora lepidophyta. As we clearly know that $R$. lepidophyta is restricted to the Devonian, this younger record is erroneous and dates from the time when what is now the latest Famennian (i.e. the Tn1a in the old Belgian nomenclature) was included within the Carboniferous. Although Archaeoperisaccus disappears from the record in the late Frasnian and Nikitinsporites in the latest Famennian, the same association of a prominently sculptured megaspore and monolete spore reoccurs (Balme 1995) in the Triassic in the plant Pleuromeia and then in extant floras as the monotypic genus Isoetes.

However, the situation has become further complicated by the rediscovery of the original material from Petino and its restudy including TEM and nanotomography (Tel'nova and Marshall 2018). At the single locality, numerous dispersed sporangia of Nikitinsporites occur together with near identical sporangia of Archaeoperisaccus that as a monolete spore had a strikingly different morphology. None of these sporangia possesses external wall layers or any form of attachment. Although the parent plant was named as Kryshtofovichia, no megafossil remains were reported in the original description. The morphological restudy reveals that the ultrastructure of Archaeoperisaccus from the Petino locality is distinctly different from dispersed specimens of Archaeoperisaccus and reveals that the group is heterogenous and probably produced by unrelated plants. So, the extinction of Nikitinsporites at the D-C boundary may be not final with the Isoetalean group becoming a long ranging lazarus taxa with a very discontinuous known range. Clearly, the situation is complex with perhaps three groups present with Archaeoperisaccus.

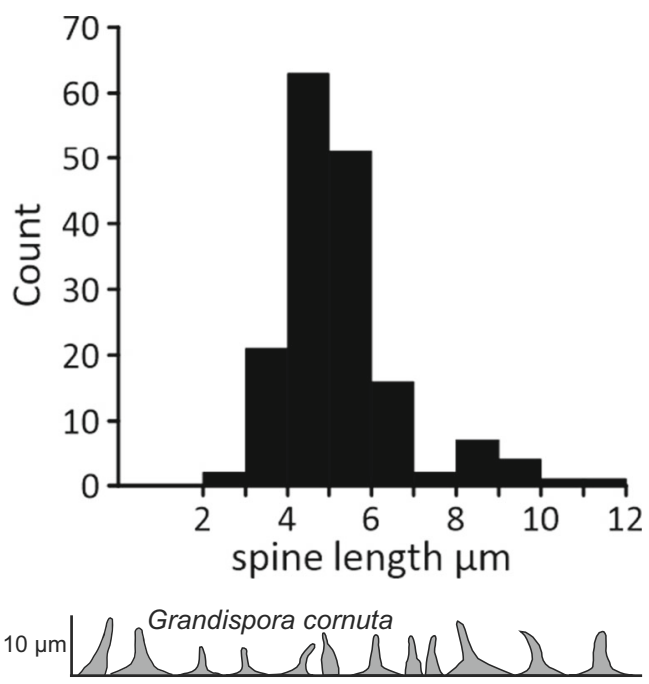

$5 \mu \mathrm{m} / \triangle \wedge \wedge \wedge \wedge \wedge \wedge \wedge$ Grandispora tamarae

Fig. 7 Histogram showing size range of sculpture of Grandispora cornuta. These have the morphology of G. cornuta spines but are shorter than in the emended description of Higgs et al. (2013). The lower sculpture figures are for Grandispora cornuta from Rebild Bakker and Grandispora tamarae taken from the illustrations in Higgs et al. (2013). This shows the two species have sculpture that differs in morphology not just size 
The three genera Ancyrospora, Hystricosporites and Nikitinspores are not the only group in the Mid and Late Devonian to possess bifurcate-tipped spines as they also occur (Richardson 1962) within Calyptosporites microspinosus. Hence, there seemed to be a trend for bifurcate tips that conferred evolutionary advantage within unrelated plant groups. The function of bifurcate tips has been discussed by several authors with suggestions ranging from arthropods as a spore dispersal vector (Kevan et al. 1975) to being an adaptation to aquatic reproduction (Dilcher et al. 1992).

\section{?Rugospora}

Another significant element in the spore flora that became extinct was Rugospora as represented by $R$. radiata. This is one species from a closely related plexus of three (Higgs et al. 2013) that represented a distinct group within Rugospora. The genus typified by two closely appressed wall layers, the outer of which is finely rugulate (ridged). There has been considerable debate (Playford and Melo 2012; Ravn 1991) about the generic status of Rugospora with many species now referred to Velamisporites. However, many of these forms differ in having a much looser external wall layer. So, to clarify relationships and D-C events, it is best to maintain them in Rugospora that defines a discrete clade that became extinct at the boundary.

\section{Taxonomic comments}

\section{?Grandispora cornuta}

Grandispora cornuta (Fig. 4i, j, k) is particularly abundant in the lower lake bed at Rebild Bakker. It is the spores with spines that express clear malformation resulting from UV-B radiation damage and given this importance is worthy of documentation. Grandispora cornuta was erected by Higgs (1975). It was subsequently emended by Higgs et al. (2013) to clearly separate it from Grandispora tamarae (see also Higgs et al. 2000). Their biometric analysis showed a clear separation based on length of sculpture with that of $G$. tamarae being less than $6 \mu \mathrm{m}$, whereas $G$. cornuta was redefined as being $>8 \mu \mathrm{m}$ and as long as $16 \mu \mathrm{m}$ in length. Analysis of the specimens of G. cornuta from Rebild Bakker (Fig. 7) shows that specimens occur with the length of the sculpture as short as $3 \mu \mathrm{m}$ to a maximum of $12 \mu \mathrm{m}$ (average $6 \mu \mathrm{m}, n=169)$, i.e. they overlap in size with $G$. tamarae. However, comparison of the type specimens of $G$. cornuta and G. tamarae shows (Fig. 7) that they also differ in the nature of the sculpture as much as spine length. Those of G. cornuta have a distinct elongated basal element sur- mounted by a longer spine that, where complete, tapers to a point. In contrast, G. tamarae has a smaller basal element that is surmounted by a minute spine that rapidly tapers to a distinct point and with a distinct triangular outline. There may be some element of thermal maturation and processing effects on these sizes. The material from East Greenland has not been oxidized and so will still include an element of size reduction from organic matter shrinkage (Piérart et al. 1981) that can be as much as $50 \%$. In contrast, the material of the type G. cornuta (Higgs 1975) and that studied in the biometric analysis by Higgs et al. (2013) which was, in part, sourced from Maziane et al. (1999) has been oxidized in Schultze solution. This causes significant swelling of the palynomorphs (Smith and Butterworth 1967) and this will contribute to the size difference.

\section{?Remysporites, Velamisporites and the spores of ?Protopitys}

Within the lower lake samples from Rebild Bakker, there is a distinctive larger spore characterised by a smooth to granular outer wall with a generally asymmetrically placed darker inner body. The size range is from 50 to $130 \mu \mathrm{m}$ with the inner and outer wall layers being quite similar in size with an internal/ external ratio of $80-90 \%$. It is distinctly different to the Auroraspora macra morphon (Van der Zwan 1980) in being larger in size and with a much less robust exoexine. There are a number of similar and related spores described in the literature as minor components in Late Devonian and Tournaisian to Namurian palynological assemblages. These include Velamisporites magnus in Higgs et al. (1988). This species was first described by Hughes and Playford (1961) from the Viséan of Spitsbergen. It is similar to but somewhat smaller than the spores described by Butterworth and Williams (1958) as Remysporites magnificus $(137-238 \mu \mathrm{m})$ from the Namurian from the Midland Valley of Scotland. Remysporites magnificus is known in situ from Paracalathiops stachei (Remy 1954) which was the fructification of the pteridosperm Rhodea. Similar spores (in fact trilete pollen) have been described (Smith 1962) from the reproductive structures of the progymnosperm plant Protopitys scotica. Smith (1962) noted that the internal spore body would be referred to the dispersed spore genus Calamospora to which can now be added Punctatisporites. To progress these initial records, larger numbers of these related spores are required from the Devonian and Carboniferous to determine how their morphology maps onto the likely in situ parent plants and to resolve how the wider group evolves through this longer time interval. The occurrence of Remysporites/Velamisporites spores within the lower lake and younger strata demonstrates the ability of seed plants to survive the perturbation. Such ideas start to inform us as the key character plants required to survive and hence the nature of the extinction mechanism. 


\section{Conclusions}

The D-C boundary record from East Greenland provides us not only with a terrestrial record of spores and pollen through the level but also with one that is at high resolution. Importantly, the section is anchored into a record of palaeoenvironmental events driven by palaeoclimate change. These sections record the extinction of four significant clades from within the Late Devonian flora and its replacement with a simple low diversity spore assemblage reflecting a recovery vegetation. Compilations of palaeobotanical and palynological literature from the long Famennian and Tournaisian stages are not able to capture accurately this geological brief event. Pollen and spores are present in high abundance, and have a high diversity and an exceptional stratigraphic record all features that make them the prime tool for studying plant diversity through time. But they do not yet have a classification that maps directly onto the megafossil plant record. When this megafossil plant record is analysed (e.g. Cascales-Miñana et al. 2018), it has an order of magnitude fewer families compared with compilations from the marine invertebrate record so any such comparison is inherently difficult. Some spores that became extinct were highly adapted such as the diverse lycopod groups with bifurcate tips. Others like Retispora lepidophyta were highly successful and the dominant element within the very latest Devonian microfloras rapidly declined and became extinct immediately below the boundary. Spores from the Rebild Bakker section show sculpture malformation entirely characteristic of UV-B damage to the DNA of the spore mother cell. This gives a context and a kill mechanism to the D-C boundary terrestrial mass extinction and is the best argument for placing the boundary at this level. This potential GSSP marker is the level we can most clearly recognise in the Greenland sections. The other candidate levels can be identified by their palaeoclimatic expression or its interaction with the overall palynological assemblage.

Acknowledgements Support from CASP has been essential for the East Greenland fieldwork and particularly assistance from the late Andy Whitham and Clive Johnson (Polar Sphere). Crucial early fieldwork was in 1996 with Tim Astin. Rich Painting, Ian Troth, Jon Lakin, Sarah Wallace-Johnson, Ed Fleming, Vincent Dupre, Simon Johnson, Chris Berry and Henning Blom variously accompanied me to the summits of Stensiö Bjerg and Rebild Bakker. Shir Akbari (Southampton) prepared the palynological samples and operated the EA-1108 elemental analyser. Markus Aretz and particularly Cyrille Prestianni are thanked for their perceptive reviews.

\section{Compliance with ethical standards}

Conflict of interest National Geographic (GEFNE52-12) part supported the 2012 field season (Fig. 2); otherwise, there was no specific grant funding for this project. I have not purchased or indeed wish to purchase, lease or otherwise any of these sections as potential GSSPs. Indeed, it is not possible to do so as they lie within a protected national park and so they should remain.

\section{Appendix}

Table 1 Taxonomic citations not in the references are in Playford and Melo (2012) or Higgs et al. (1988)

Ancyrospora capillata Dolby and Neves, 1970

Apiculiretusispora fructicosa Higgs, 1975

Auroraspora asperella (Kedo) Van der Zwan, 1980

Auroraspora solisorta Hoffmeister, Staplin and Malloy, 1955

Claytonispora rarisetosa (Kedo) Playford and Melo, 2012

Convolutisporites major (Kedo) Turnau, 1978

Cyrtospora cristifer (Luber) Van der Zwan, 1979

Diducites mucronatus (Kedo) Van Veen, 1981

Diducites versabilis (Kedo) Van Veen, 1981

Endoculeosporites gradzinskii Turnau, 1975

Gorgonispora crassa (Winslow) Higgs, Clayton and Keegan, 1988

Grandispora cornuta Higgs, 1975

Grandispora echinata Hacquebard, 1957

Grandispora uncata (Hacquebard) Playford, 1971

Grandispora senticosa (Ischenko) Byvsheva, 1985

Indotriradites explanatus (Luber in Luber and Waltz) Playford, 1991

Knoxisporites literatus (Waltz) Playford, 1963

Knoxisporites triangularis Higgs, Clayton and Keegan, 1988

Raistrickia variabilis Dolby and Neves, 1970

Retispora lepidophyta (Kedo) Playford, 1976

Retispora macroreticulata (Kedo) Byvscheva, 1985

Retusotriletes incohatus Sullivan, 1964

Rugospora radiata (Jushko) Byvscheva, 1985

Tergobulasporites immensus (Nazarenko and Nekriata) Turnau, 2002

Tumulisporora rarituberculata (Luber in Luber and Waltz) Playford, 1991

Vallatisporites verrucosus Hacquebard, 1957

Vallatisporites pusillites (Kedo) Dolby and Neves, 1970

Verrucosisporites nitidus Playford, 1964

Verrucosisporites oppressus (Higgs) Higgs, Clayton and Keegan, 1988

Open Access This article is licensed under a Creative Commons Attribution 4.0 International License, which permits use, sharing, adaptation, distribution and reproduction in any medium or format, as long as you give appropriate credit to the original author(s) and the source, provide a link to the Creative Commons licence, and indicate if changes were made. The images or other third party material in this article are included in the article's Creative Commons licence, unless indicated otherwise in a credit line to the material. If material is not included in the article's Creative Commons licence and your intended use is not permitted by statutory regulation or exceeds the permitted use, you will need to obtain permission directly from the copyright holder. To view a copy of this licence, visit http://creativecommons.org/licenses/by/4.0/.

\section{References}

Astin, T. R., Marshall, J. E. A., Blom, H., \& Berry, C. M. (2010). The sedimentary environment of the Late Devonian East Greenland 
tetrapods. In M. Vecoli, G. Clément \& B. Meyer-Berthaud (Eds.) The terrestrialization process: modelling complex interactions at the biosphere-geosphere interface, 339 (93-109). Special Publication Geological Society of London.

Bábek, O. J., Kumpan, T., Kalvoda, J., \& Grygar, T. M. (2016). Devonian/Carboniferous boundary glacioeustatic fluctuations in a platform-to-basin direction: a geochemical approach of sequence stratigraphy in pelagic settings. Sedimentary Geology, 337, 81-99.

Balme, B. E. (1995). Fossil in situ spores and pollen grains: an annotated catalogue. Review of Palaeobotany and Palynology, 87, 81-323.

Batten, D. J., \& Grenfell, H. R. (1996). 7D Botryococcus. In J. Jansonius \& D. C. McGregor (Eds.) Palynology: principles and applications. American Association of Stratigraphic Palynologists Foundation, 1, 205-214.

Becker, R. T., Kaiser, S. I., \& Aretz, M. (2016). Review of chrono-, lithoand biostratigraphy across the global Hangenberg Crisis and Devonian-Carboniferous Boundary. Geological Society of London, Special Publication, 423, 387-437.

Blom, H., Clack, J. A., \& Ahlberg, P. E. (2005). Localities, distribution and stratigraphical context of the Late Devonian tetrapods of East Greenland. Meddelelser om Grønland Geoscience, 43, 1-50.

Blom, H., Clack, J. A., Ahlberg, P. E., \& Friedman, M. (2007). Devonian vertebrates from East Greenland: a review of faunal composition and distribution. Geodiversitas, 29, 119-141.

Butterworth, M. A., \& Williams, R. W. (1958). The small spore floras of coals in the Limestone Coal Group and the Upper Limestone Group of the lower Carboniferous of Scotland. Transactions of the Royal Society of Edinburgh, 63, 353-392.

Cascales-Miñana, B. (2016). Apparent changes in the OrdovicianMississippian plant diversity. Review of Palaeobotany and Palynology, 227, 19-27.

Cascales-Miñana, B., Servais, T., Cleal, C. J., Gerrienne, P., \& Anderson, J. (2018). Plants the great survivors! Geology Today, 34, 224-229.

Chaloner, W. G. (1959). Devonian megaspores from Arctic Canada. Palaeontology, 1, 321-332.

Clausen, C-D., Korn, D., Feist, R., Leuschner, K., Groos-Uffenorde, H., Luppold, F. W., et al. (1994). Die Devon/Karbon-Grenze bei Stockum (Rheinisches Schiefergebirge). Geologie und Paläontologie in Westfalen, 29, 71-95.

Clausen, C.-D., Leuteritz, K., Ziegler, W., \& Korn, D. (1989). Ausgewählte Profile an der Devon/Karbon Grenze im Sauerland (Rheinisches Schiefergebirge). Fortschritte in der Geologie von Rheinland und Westfalen, 35, 161-226.

Coxall, H. K., Wilson, P. A., Pälike, H., Lear, C. H., \& Backman, J. (2005). Rapid stepwise onset of Antarctic glaciation and deeper calcite compensation in the Pacific Ocean. Nature, 433, 53-57.

Dilcher, D. L., Kar, R. K., \& Dettmann, M. E. (1992). The functional biology of Devonian spores with bifurcate processes-a hypothesis. Palaeobotanist, 41, 67-74.

Edwards, D., Fairon-Demaret, M., \& Berry, C. M. (2000). Plant megafossils in Devonian stratigraphy: a progress report. Courier Forschungsinstitut Senckenberg, 220, 25-37.

Ehrmann, W., Schmeidel, G., Beuscher, S., \& Krüger, S. (2017). Intensity of African humid periods estimated from Saharan dust fluxes. PLoS One, 12, e0170989.

Ettensohn, F. R., Seckinger, D. C., Eble, C. F., Clayton, G., Li, J., Martins, G. A., Hodelka, B. N., Lo, E. L., Harris, F. R., \& Taghizadeh, N. (2020). Age and tectonic significance of diamictites at the Devonian-Mississippian transition in the central Appalachian Basin. In C. S. Swezey \& M.W. Carter (Eds.) Geology field trips in and around the U.S. Capital: Geological Society of America Field Guide, 57, 79-103.

Filipiak, P., \& Racki, G. (2010). Proliferation of abnormal palynoflora during the end-Devonian biotic crisis. Geological Quarterly, 54, 114.
Gao, L. (1989). Palynostratigraphy at the Devonian-Carboniferous Boundary in the Himalayan Region, Xizang (Tibet). In N. J. McMillan, A. F. Embry, \& D. J. Glass (Eds.) Devonian of the World; Proceedings of the Second International Symposium on the Devonian System. Canadian Society of Petroleum Geologists, Memoir 14(III), 159-170.

Gradstein, F. M., Ogg, J. G., Schmitz, M. \& Ogg, G. (2020) Geological time scale. Elsevier.

Greb, S. F., DiMichele, W. A., \& Gastaldo, R. A. (2006). Evolution and importance of wetlands in Earth history. Geological Society of America Special Paper, 399, 1-40.

Higgs, K. (1975). Upper Devonian and Lower Carboniferous miospore assemblages from Hook Head, County Wexford, Ireland. Micropalaeontology, 21, 393-419.

Higgs, K. T., \& Streel, M. (1994). Palynological age for the lower part of the Hangenberg Shales in the Sauerland, Germany. Annales de la Société Géologique de Belgique, 116, 243-247.

Higgs, K., Clayton, G., \& Keegan, J. B. (1988). Stratigraphic and systematic palynology of the Tournaisian rocks of Ireland. The Geological Survey of Ireland, Special Paper Number, 7, 1-93.

Higgs, K. T., Streel, M., Korn, D., \& Paproth, E. (1993). Palynological data from the Devonian-Carboniferous boundary beds in the new Stockum Trench II and the Hasselbachtal borehole, Northern Rhenish Massif, Germany. Annales de la Société Géologique de Belgique, 115, 551-557.

Higgs, K., Avkhimovitch, V. I., Loboziak, S., Maziane-Serraj, N., Stempien-Salek, M., \& Streel, M. (2000). Systematic study and stratigraphic correlation of the Grandispora complex in the Famennian of northwest and eastern Europe. Review of Palaeobotany and Palynology, 112, 207-228.

Higgs, K. T., Prestianni, C., Streel, M., \& Thorez, J. (2013). High resolution miospore stratigraphy of the Upper Famennian of eastern Belgium, and correlation with the conodont zonation. Geologica Belgica, 16, 289-295.

Hughes, N. F., \& Playford, G. (1961). Palynological reconnaissance of the Lower Carboniferous of Spitsbergen. Micropalaeontology, 7, $27-44$.

Kaiser, S. I., Aretz, M., \& Becker, R. T. (2016). The global Hangenberg Crisis (Devonian-Carboniferous transition): review of a first-order mass extinction. In R. T. Becker, P. Königshof, \& C. E. Brett (Eds.) Devonian climate, sea level and evolutionary events. 423(pp. 387437) Geological Society of London, Special Publication.

Kevan, P. G., Chaloner, W. G., \& Savile, D. B. O. (1975). Interrelationships of early terrestrial arthropods and plants. Palaeontology, 18, 391-417.

Kodrans-Nsiah, M., März, C., Harding, I. C., Kasten, S., \& Zonneveld, K. A. F. (2009). Are the Kimmeridge Clay deposits affected by "burndown" events? Palynological and geochemical studies on a 1 metre long section from the Upper Kimmeridge Clay Formation (Dorset, UK). Sedimentary Geology, 222, 301-313.

Lakin, J. A., Marshall, J. E. A., Troth, I., \& Harding, I. C. (2016). Greenhouse to icehouse: a biostratigraphic review of latest Devonian-Mississippian glaciations and their global effects. In R. T. Becker, P. Königshof \& C. E. Brett (Eds.) Devonian climate, sea level and evolutionary events 423(pp. 439-464) Geological Society, London, Special Publication.

Larsen, P.-H., Olsen, H., \& Clack, J. A. (2008). The Devonian Basin in East Greenland - review of basin evolution and vertebrate assemblages. GSA Memoir, 202, 273-292.

Marshall, J. E. A. (1996). Vegetational history of Devonian spores. In J. Jansonius \& D. C. McGregor (Eds.) Palynology: principles and applications. American Association of Stratigraphic Palynologists Foundation, 3, 1133-1141.

Marshall, J. E. A., \& Allen, K. C. (1982). Devonian miospore assemblages from Fair Isle, Shetland. Palaeontology, 25, 277-312. 
Marshall, J. E. A., \& Astin, T. R. (1996). An ecological control on the distribution of the Devonian fish Asterolepis. Newsletters in Stratigraphy, 33, 133-144.

Marshall, J. E. A., \& Fletcher, T. P. (2002). Middle Devonian (Eifelian) spores from a fluvial dominated lake margin in the Orcadian Basin, Scotland. Review of Palaeobotany \& Palynology, 118, 195-209.

Marshall, J. E. A., \& Hemsley, A. R. (2003). A Mid Devonian seedmegaspore from East Greenland and the origin of the seed plants. Palaeontology, 46, 647-670.

Marshall, J. E. A., \& Stephenson, B. J. (1997). Sedimentological responses to basin initiation in the Devonian of East Greenland. Sedimentology, 44, 407-419.

Marshall, J. E. A., Astin, T. R., \& Clack, J. A. (1999). The East Greenland tetrapods are Devonian in age. Geology, 27, 637-640.

Marshall, J. E. A., Astin, T. R., Brown, J. F., Mark-Kurik, E., \& Lazauskiene, J. (2007). Recognising the Kačák Event in the Devonian terrestrial environment and its implications for understanding land-sea interactions. In R. T. Becker \& W. T. Kirchgasser (Eds.) Devonian events and correlations 278(pp. 133155). Special Publication of the Geological Society of London.

Marshall, J. E. A., Glennie, K. W., Astin, T. R., \& Hewett, A. J. (2019a). The Old Red Group (Devonian)-Rotliegend (Permian) unconformity in the Inner Moray Firth. In A. A. Monaghan, J. R. Underhill, A. J. Hewett \& J. E. A. Marshall (Eds.) Paleozoic plays of NW Europe, 471 (237-252). Geological Society, London, Special Publications.

Marshall, J. E. A., Reeves, E. J., Bennett, C. E., Davies, S. J., Kearsey, T. I., Millward, D., Smithson, T. R., \& Browne, M. A. E. (2019b). Reinterpreting the age of the uppermost 'Old Red Sandstone' and Early Carboniferous in Scotland. Earth and Environmental Science Transactions of the Royal Society of Edinburgh, 109, 265-278.

Marshall, J. E. A., Lakin, J., Troth, I., \& Wallace-Johnson, S. M. (2020). UV-B radiation was the Devonian-Carboniferous terrestrial extinction kill mechanism. Science Advances, 6, eaba0768. https://doi.org/ 10.1126/sciadv.aba0768.

Maziane, N., Higgs, K. T., \& Streel, M. (1999). Revision of the late Famennian miospore zonation scheme in eastern Belgium. Journal of Micropalaeontology, 18, 17-25.

Maziane, N., Higgs, K. T., \& Streel, M. (2002). Biometry and paleoenvironment of Retispore lepidophyta (Kedo) Playford 1976 and associated miospores in the latest Famennian nearshore marine facies, eastern Ardenne (Belgium). Review of Palaeobotany and Palynology, 118, 211-226.

McGregor, D. C. (1969). Devonian plant fossils of the genera Kryshtofovichia, Nikitinsporites, and Archaeoperisaccus. Bulletin Canadian Geological Survey, 182, 91-93.

Millward, D., Davies, S. J., Brand, P. J., Browne, M. A. E., Bennett, C. E., Kearsey, T. I., Sherwin, J. E., \& Marshall, J. E. A. (2019). Palaeogeography of tropical seasonal coastal wetlands in northern Britain during the early Mississippian Romer's Gap. Earth \& Environmental Transactions Royal Society Edinburgh, 109, 279300 .

Nikitin, A. P. (1934). Fossil plants from the Petino Horizon of the Devonian of the Voronezh Region. Izvestiya Akademii Nauk SSSR ser Geologicheskaya, 1934, 1079-1090.

Olsen, H. (1993). Sedimentary basin analysis of the continental Devonian basin in North-East Greenland. Bulletin of the Grønlands Geologiske Undersøgelse, 168, 1-80.

Olsen, H. (1994). Orbital forcing on continental depositional systemslacustrine and fluvial cyclicity in the Devonian of East Greenland. Special Publications of the International Association of Sedimentologists, 19, 429-438.

Olsen, H., \& Larsen, P.-H. (1993). Lithostratigraphy of the continental Devonian sediments in North-East Greenland. Bulletin of the Grønlands Geologiske Undersøgelse, 165, 1-108.

Parnell, J., Carey, P., \& Monson, B. (1998). Timing and temperature of decollement on hydrocarbon source rock beds in cyclic lacustrine successions. Palaeogeography, Palaeoclimatology, Palaeoecology, 140, 121-134.

Pas, D., Hinnov, L., Day, J. E., Kodama, K., Sinnesael, M., \& Liu, W. (2018). Cyclostratigraphic calibration of the Famennian stage (Late Devonian, Illinois Basin, USA). Earth and Planetary Science Letters, 388, 102-114.

Piérart, P., Postiau, P., \& Roisin, M. A. (1981). Changes in sporopollenin during thermal treatment. In J. Brooks (Ed.) Organic maturation studies and fossil fuel exploration (pp. 53-73). London: Academic Press.

Playford, G., \& Melo, J. H. G. (2012). Miospore palynology and biostratigraphy of Mississippian strata of the Amazonas Basin, northern Brazil. American Association of Stratigraphic Palynologists, Contributions Series, 47, 1-201.

Prestianni, C., Sautois, M., \& Denayer, J. (2016). Disrupted continental environments around the Devonian-Carboniferous Boundary: introduction of the tener event. Geologica Belgica, 19, 135-145.

Ravn, R. L. (1991). Miospores of the Kekiktuk Formation (Lower Carboniferous), Endicott field area, Alaska North Slope. American Association of Stratigraphic Palynologists, Contributions Series, $27,1-173$.

Remy, W. (1954). Die Systematic der Pteridospermem unter Berücksichtigung ihrer Pollen. Geologie, 3, 312-325.

Richardson, J. B. (1962). Spores with bifurcate processes from the Middle Old Red Sandstone of Scotland. Palaeontology, 5, 171-194.

Richardson, J. B. (1969) Devonian spores. In R. H. Tschudy, \& R. A. Scott (Eds.) Aspects of Palynology (pp. 193-222). New York: Wiley.

Rogers, D. A., \& Astin, T. R. (1991). Ephemeral lakes, mud pellet dunes and wind-blown sand and silt: reinterpretations of Devonian lacustrine cycles in north Scotland. In P. Anadon, L. Cabrera, \& K. Kelts (Eds.) Lacustrine facies analysis. Special Publications International Association. of Sedimentologists, 13, (pp. 199-221). Oxford: Blackwell Scientific Publications.

Sallan, L. C., \& Coates, M. I. (2010). End-Devonian extinction and a bottleneck in the early evolution of modern jawed vertebrates. PNAS, 107, 10131-10135.

Scheckler, S. E. (1986). Geology, floristics and palaeoecology of Late Devonian coal swamps from Appalachian Laurentia (U.S.A.). Annales de la Société Géologique de Belgique, 109, 209-222.

Silvestro, D., Cascales-Miñana, B., Bacon, C. D., \& Antonelli, A. (2015). Revisiting the origin and diversification of vascular plants through a comprehensive Bayesian analysis of the fossil record. New Phytologist, 207, 425-436.

Smith, D. L. (1962). Three fructifications from the Scottish Lower Carboniferous. Palaeontology, 5, 225-237.

Smith, A. H. V., \& Butterworth, M. A. (1967). Miospores in the coal seams of the Carboniferous of Great Britain. Special Papers in Palaeontology, 1, 1-324.

Smith, A. G., Barry, T., Bown, P., Cope, J., Gale, A., Gibbard, P., Gregory, J., Hounslow, M., Kemp, D., Knox, R., Marshall, J., Oates, M., Rawson, P., Powell, J., \& Waters, C. (2015). GSSPs, global stratigraphy and correlation. In D. G. Smith, R. J. Bailey, P. M. Burgess \& A. J. Fraser (Eds.) Geological Society, London, Special Publications, 404, 37-67.

Streel, M. (1966). Critères palynologiques pour une stratigraphie détailée du Tnla dans les bassins Ardenno-Rhénans. Annales de la Société Géologique de Belgique, 89, 65-96.

Streel, M. \& Marshall, J. E. A. (2006) Devonian-Carboniferous boundary global correlations and their paleogeographic implications for assembly of Pangaea. In Wong, Th. E. (ed.) Proceedings of the XVth International Congress on Carboniferous and Permian Stratigraphy. Utrecht, the Netherlands, 10-16 August 2003. Royal Netherlands Academy of Arts and Sciences, 481-496.

Streel, M., \& Scheckler, S. E. (1990). Miospore lateral distribution in upper Famennian alluvial lagoonal to tidal facies from eastern 
United States and Belgium. Review of Palaeobotany and Palynology, 64, 315-324.

Streel, M., Caputo, M. V., Melo, J. H. G., \& Perez-Leyton, M. (2013). What do latest Famennian and Mississippian miospores from South American diamictites tell us? Palaeobiodiversity and Palaeoenvironments, 93, 299-316.

Tel'nova, O. P., \& Marshall, J. E. A. (2018). Devonian spores of Kryshtofovichia africani Nikitin (Tracheophyta): morphology and ultrastructure. Palaeontological Journal, 52, 342-349.

Torsvik, T. H. \& Cocks, L. R. M. (2017) Earth history and palaeogeography, CUP.

Traverse, A. (1988). Plant evolution dances to a different beat. Historical Biology, 1, 277-301.

Traverse, A. (1990). Plant evolution in relation to world crises and the apparent resilience of Kingdom Plantae. Palaeogeography, Palaeoclimatology, Palaeoecology, 82, 203-211.

Troth, I., Marshall, J. E. A., Racey, A., \& Becker, R. T. (2011). Middle Devonian sea-level change at high palaeolatitude: testing the global sea-level curve. Palaeogeography, Palaeoclimatology, Palaeoecology, 304, 3-20.

Turnau, E. (2002). Two new Devonian spore genera from Euramerica and their stratigraphic and geographic distribution. Review of Palaeobotany and Palynology, 118, 261-268.

Turnau, E., Avchimovitch, V. I., Byvscheva, T. V., Clayton, G., Higgs, K. T., \& Owens, B. (1994). Taxonomy and stratigraphical distribution of Verrucosisporites nitidus Playford, 1964 and related species. Review of Palaeobotany and Palynology, 81, 289-295.

Veen, P. M. van (1981). Aspects of late Devonian and early Carboniferous palynological assemblages at the DevonianCarboniferous boundary. Review of Palaeobotany and Palynology, 34, 67-97.

Vigran, J. O., Stemmerik, L., \& Piasecki, S. (1999). Stratigraphy and depositional evolution of the uppermost Devonian-Carboniferous (Tournaisian-Westphalian) non-marine deposits in North-East Greenland. Palynology, 23, 115-152.

Wellman, C. H. (2002). Morphology and wall ultrastructure in Devonian spores with bifurcate-tipped processes. International Journal of Plant Science, 163, 451-474.

Wicander, R., Clayton, G., Marshall, J. E. A., Troth, I., \& Racey, A. (2011). Was the latest Devonian glaciation a multiple event? New palynological evidence from Bolivia. Palaeogeography, Palaeoclimatology, Palaeoecology, 305, 75-83.

Zwan, C. J. van der (1980). Aspects of Late Devonian and Early Carboniferous palynology of southern Ireland. II. The Auroraspora macra morphon. Review of Palaeobotany and Palynology, 30, 133-155.

Publisher's note Springer Nature remains neutral with regard to jurisdictional claims in published maps and institutional affiliations. 